\title{
TESTS OF PRESTRESSED CONCRETE BEAM SPLICES
}

\section{SEPTEMBER 1969 - NUMBER 22}

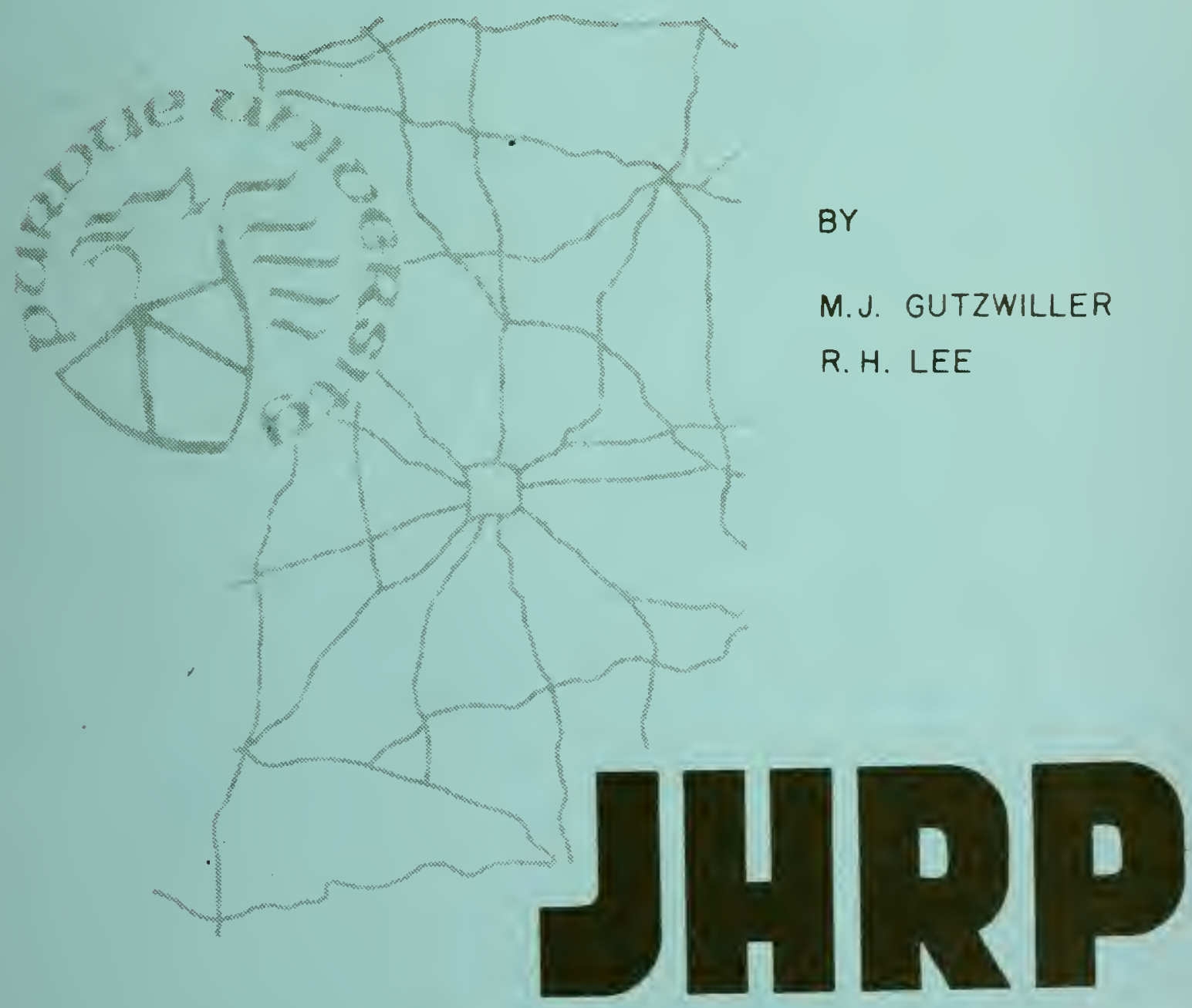

JOINT HIGHWAY RESEARCH PROJECT PURDUE UNIVERSITY AND 

Final Report

TESTS OF PRESTRESSED CONCRETE

BEAM SPLICES

by

M.J. Gutzwiller, Research Engineer

and

R。H. Lee, Research Engineer

Joint Highway Research Project

File No: 7-4-i6

Project No: C-36-56P

This research investigation was conducted in cooperation and with the assistance of the Indiana State Highway Commission and the Prestressed Concrete Producers of Indiana .

Purdue University

Lafayette, Indiana

Juiy 25, 1969 
Digitized by the Internet Archive in 2011 with funding from

LYRASIS members and Sloan Foundation; Indiana Department of Transportation 


\section{TESTS OF PRESTRESSED CONCRETE \\ BEAM SPLICES}

TO: j. F。 McIaughlin, Director

Joint Highway Research Projact

FROM: H. L。 Michae1, Associate Director Joint Highway Research Project
Ju1y 25, 1969

File No: 7-4-16

Project No: $8-36-56 P$

The attached Final Repcrt entitled "Tests of Prestressed Concrete Beam Splices" has been prepared by Professors M.J. Gutzwiller and R. $H$. Lee of our staff. The study was performed with the assistance and cooperation of the Indiana State Highway Commission and the Frestressed Concrete Producers of Indiana.

The report contains the lesults of tests made on three types of prestressed beam splices. An analysis and discussion of the tests for each type is presented.

The Erestressed Concrete Producers of Indiana wish to obtain a supply of these reports and release of the report to them is requested.

Respectfully submitted,

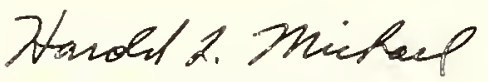

Harold L. Michael

Associate Director

\section{$H L M / r g$}

cc: F。 L. Ashbascher
W. L. DoIch
W. H. Goetz
W. I. Grecco
G. R. HaIlock
M. E. Harr

R. H. Harrell

$J$. A. Havers

V.E. Harvey

F. B. Mendenha11

R. D. Miles
C. F. Scholer

M. B. Scott

W. T. Spencer

I. R。 J。Walsh

K. B. Woods

E. J. Yoder 


\section{Introduction}

Bridge span lengths have been steadily increasing throughout history, caused by changing technology and design criteria. A typical example of changing criteria may be fourd in the Interstate Highway construction program, which presently accounts for a large volume of bridge work. Safety standards now used in bridge design require bridge abutments to be located considerably farther from the pavement edge than previously. This change in criteria, coupled with standard median widths, roadway widths, etc. requires span lengths of around 100 feet for overpasses having no skew. As span length recuirements increase, changes in technology are needed to economically fulfill the new criteria.

Prestressed concrete beams have been used in a growing proportion of the bridge superstructures. In the Inited States, most of the prestressed concrete work has been accomplished with precast beams, manufactured at a fixed plant and transported to the construction site for erection. The beams are commoniy pretensioned, i.e., the prestressing tendons are stretched between permanent anchorages. Concrete is then placed in the forms and cured, bonding to the steel. The tendons are then released, compressing the concrete. Pretensioning requires massive anchorages, extensive handling facilities and concrete batching machinery. A large capital outlay is inherent, and the operation is well suited for mass production methods.

The sequence of events is slightly different in the manufacture of post-tensioned beams. Concrete for post-tensioned members is placed with a void space for the tendons. After the concrete has gained sufficient strength, the tendons are stressed by jacking against the beam itselfo 
In general the terms pre and post refer to the timing of the tendon stressing operation, either before or after concrete placement. Postatensioning does not require a large fixed plant, but the method is not readily amenable to mass production of beams. It may be used efficiently for site casting of large members.

Since most prestressed concrete work in the United States is accomplisted by pre-tensioning, the problem of transportation to the construction site remains. Bridge spans of 100 feet or more require transfortation of rather long members, usually over the public highways. While a few passages of long members might be considered as occasioral events, highway authorities are becoming more reluctant to grant over-length permits on a daily, continuing basis. Hauling restrictions for prestressed beams indicate the need for field splicing of the precast members when long spans are encountered.

The Prestressed Concrete Institute recognized the need for splicing and presented a number of possible field splices in a recent publication. However, the available test data on how certain of these splices function are somewhat limited. The Prestressed Concrete Producers of Indiana (PCPI), which is an organization of manufacturers, would like to use sone of these splices in future bridge work. In order to determine splice behavior, the producer's association undertook a full scale test of three different splice types. The actual design of the splices was done in the Bridge Design Section of the Indiana State Highway Commission. Beams were fabricated by Construction Products Corporation in Lafayette, Indiana. Tests were performed at the company's casting yard. The tests were moritored by staff members of the Joint Highway Research Project at Rurdue University。

(1) "Prestressed Concrete for Long Span Bridges" published by Prestressed Concrete Institute, 1968 . 
One specimen of each splice type was testad. The three tasts were made on May 15, 1969, with a number of manufacturer representatives, state highway and other interested personnel present.

Each splice type is described separately in the report. Construction details, test procedure, results and discussion are given. It should be pointed out that the beam lengths chosen were dictated by the testing frame and equipment. The beams are essentially full size for the span lengths on which they were tested. Extrapolation from a 40 foot test span to a 120 foot field span should not incur any unexpected results. Design calculations for the various splices are not included in this report. If information on these caiculations is desired, contact the Bridge Design Section, Indiana State Highway Department, Indianapolis, Indiana 46204.

\section{POST-TENSIONED SPIICE}

\section{Background:}

One type of splicing situation which may arise is indicatsd in Figure 1. The use illustrated is that of a simple span beam, spliced in the region of high bending moment. (There are other possible configurations where this splice may prove useful.?

The splice connects two precast beams by using post-tensioning cabies threaded through ducts in the adjoining members. A thin layer cf grout between the two beans is used to grovide an even bearing surface. The beams are temporarily shored wile the cables are threaded, the grout packed and a cast-in-place deck slab placed. The cables are then stressed, permitting removal of the shores. Grouting of the void space bonds the cables to the beams. The post-tensioning cables provide the connecting link between the precast beams. The precast beams contain a mincr amount of pre-tensioning steel to prevent cracking during handing and transportation. 
CAST-IN-PLACE SLAB

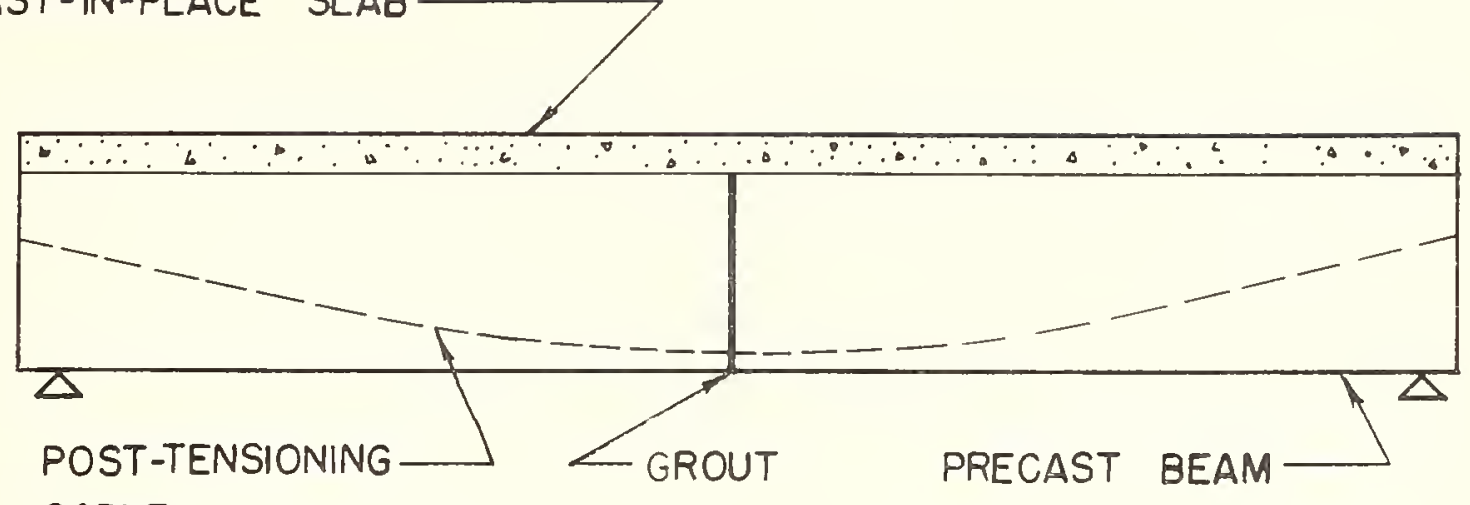

CABLE

FIGURE 1. POST-TENSIONED SPLICE - GENERAL ARRANGEMENT

HYDRAULIC JACK REACTING

AGAINST LOAD FRAME

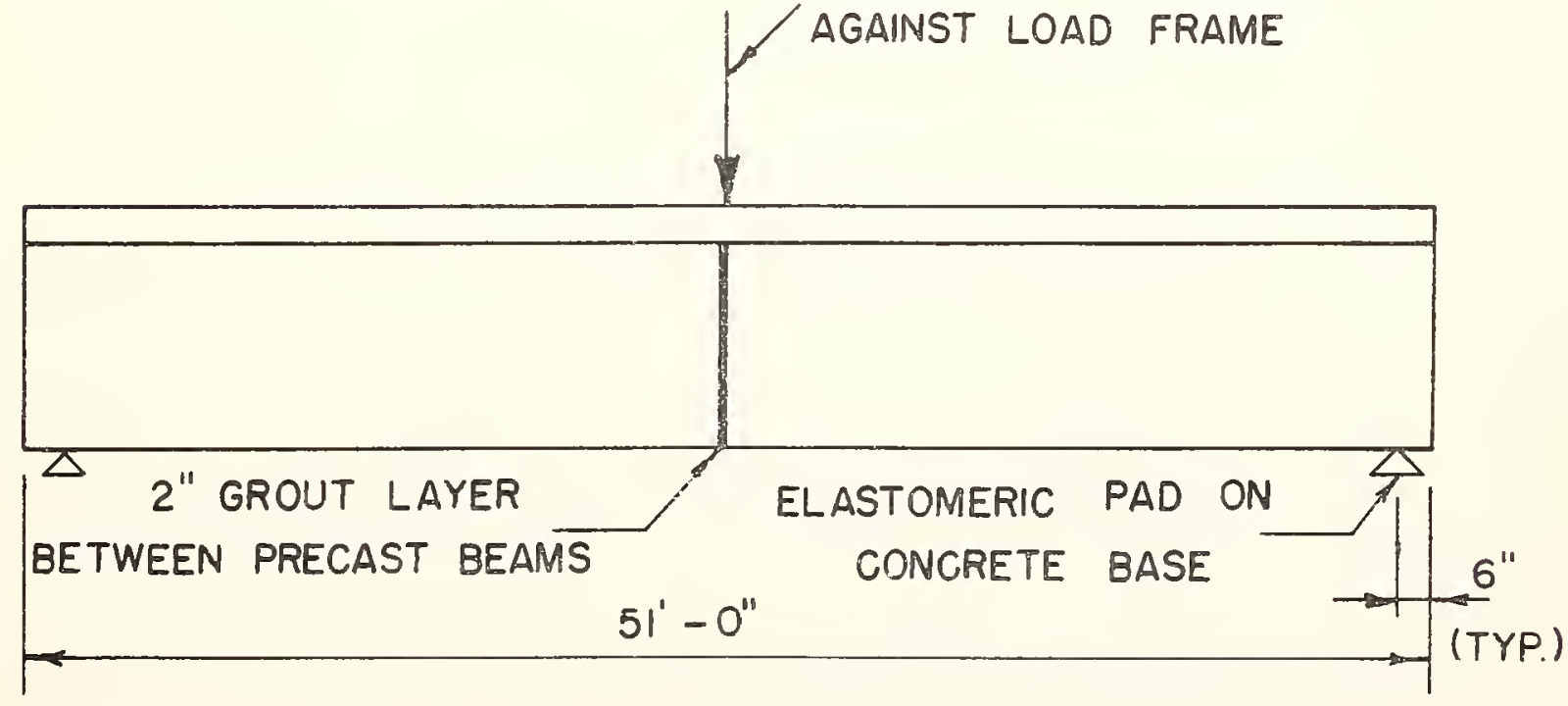

FIGURE 2. POST-TENSIONED SPLICE - LOAD ARRANGEMENT 
Details of Test Beam

The test beam had an overall lergth of 51 '-0". A Type I AASHO I-beam was used, with end blocks to facilitate transfer of the concentrated posttensioning forces at the ends. Extra stirrups and a reinforcing grid were placed in the end blocks. Figures 2 and 3 show the load arrangement and beam details in section and elevation. Two post-tensioning cables were

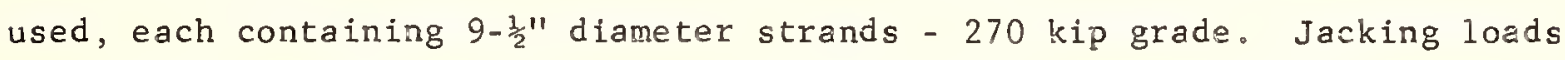
were 278 kips per cable. The cables were draped parabolically through the span. Four $7 / 16^{\circ} 270$ kip pre-tensioning strands were provided for handling stresses. The beams were made on May 7, 1969.

The grout layer was two inches wide and was placed on May 9, 1969. A $5^{\prime}-0^{\prime \prime}$ wide slab, $7^{\prime \prime}$ thick, was cast to simulate the deck that would be used in the prototype. Stirrups extending through the top of the beam provided shear connection to the slab.

Concrete was mixed in the batch plant of Construction Products Corporation. Table 1 gives the cylinder strengths obtained for the concrete in the beams and composite slab.

Table 1. Concrete Cylinder Strengths Post-tensioned Splice

\begin{tabular}{|l|c|c|c|}
\hline \multirow{2}{*}{ Member } & \multicolumn{2}{|c|}{$6^{\prime \prime} \times 12^{\prime \prime}$ Cylinder compressive strengths } \\
\hline & 1 day & 7 days & 28 days \\
\hline Beam & $3790 \mathrm{psi}$ & $4990 \mathrm{psi}$ & $5380 \mathrm{psi}$ \\
Slab & $4180 \mathrm{psi}$ & $5060 \mathrm{psi}$ & $5440 \mathrm{psi}$ \\
\hline
\end{tabular}

* Average of three cylinders

At the time of testing, beams were 8 days old and the slab was 5 days old. The grout layer between beams was placed 6 days prior to testing. The post-tensioning cables were stressed and grouted 24 hours prior to the test. While no cylinder strengths were obtained for the grout, it appeared that the 


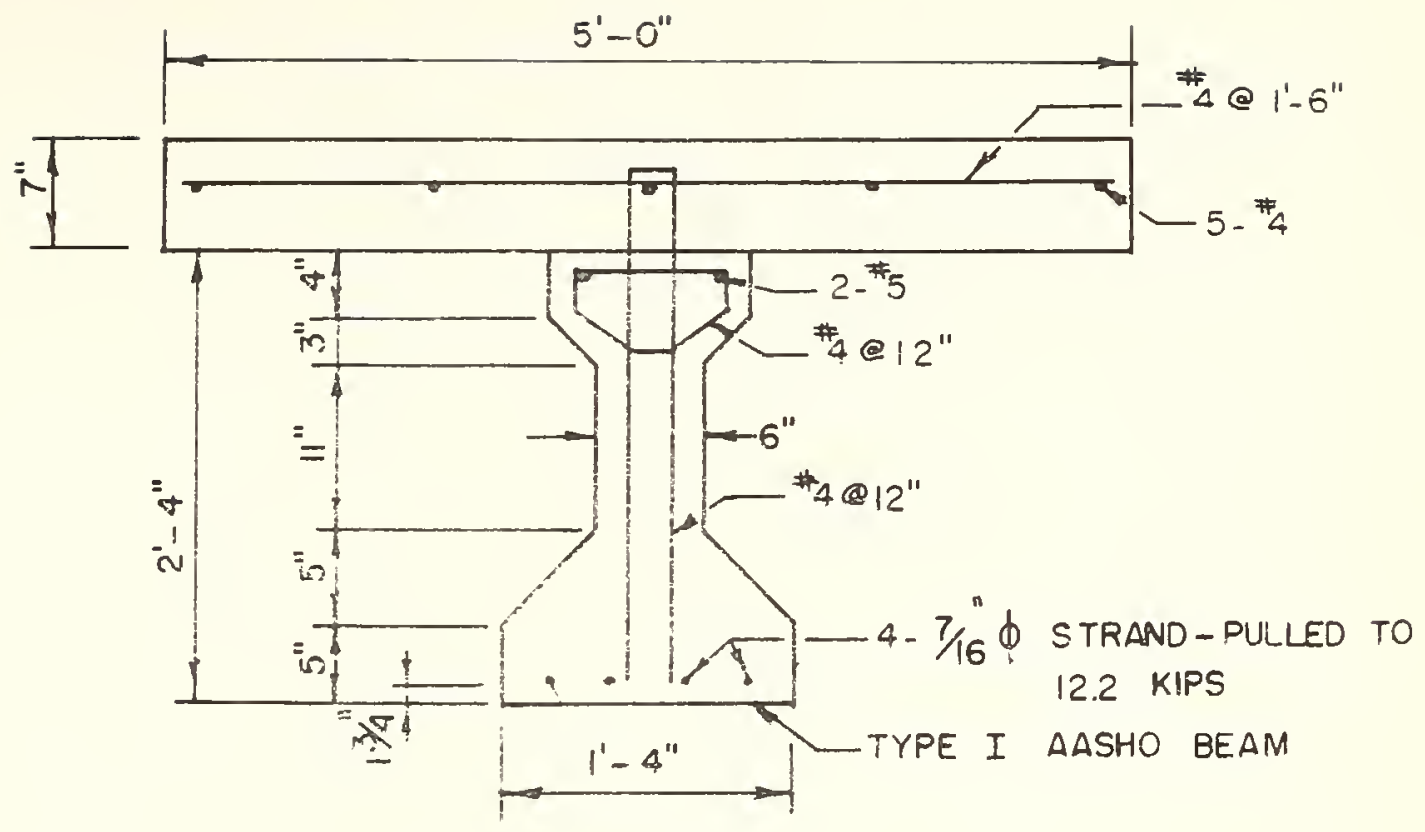

(A) SECTION

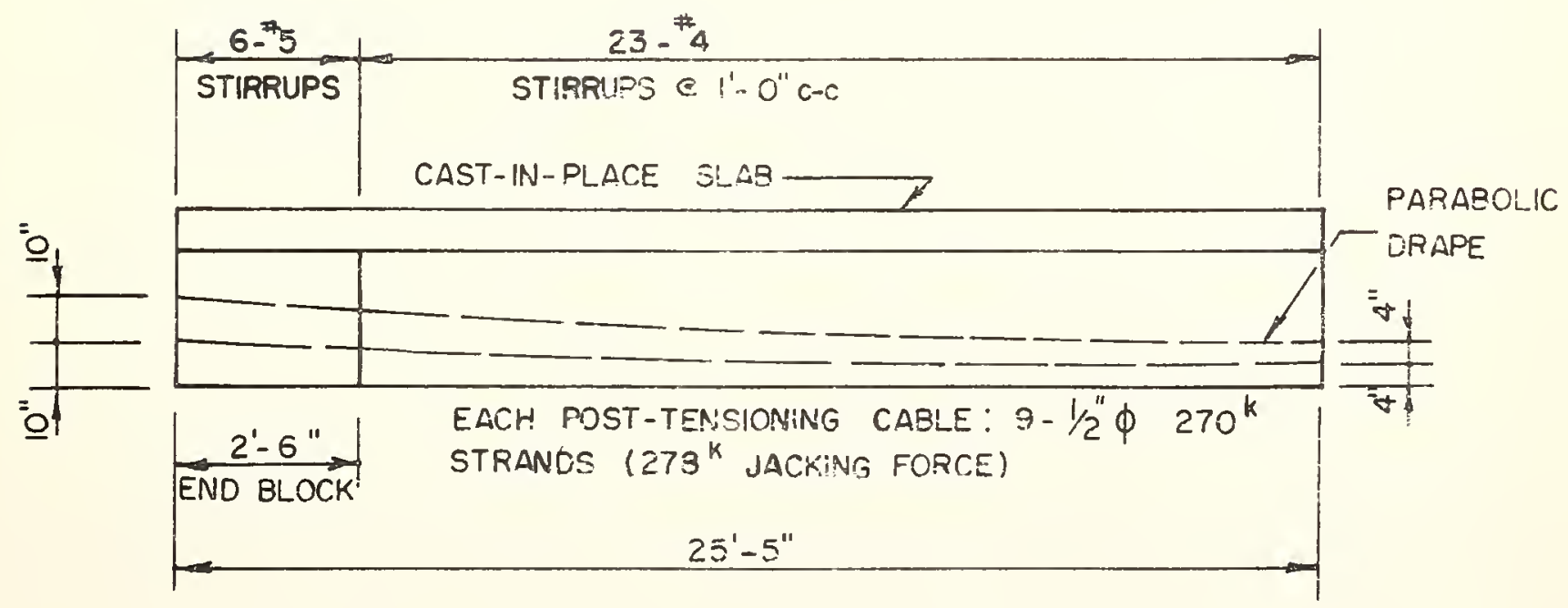

(B) ELEVATION

FIGURE 3. POST-TENSIONED SPIICE - DETAILS 
grout was not of good quality. It was rather soft and could be removed by scraping with a metal instrument. When the cables were stressed, a crack appeared in the concrete slab directly over the grout joint, extending from the top of the slab to a depth of about 6 inches. Crack width was about $0.06 "$ at the top. Theoretical stress calculations at this point indicated compression throughout the depth of the member. Apparently the grout had a much lower stiffness modulus than the siab concrete, causing the grout to shorten more under compression than anticipated. In other words, the grout material at the splice was not of a stiffness comparabie to the other components, as assumed in the original stress anaiysis.

Initial upward camber after post-tensioning was 2.44 inches at the centerline of span.

\section{Test Procedure}

The specimen was loaded through a hydraulic jack at the centerline of the span. The jack reacted against a steel test frame boltel to the foundation. Elastomeric bearing pads were used at the end bearings and between the jack and the slab. The jack had a capacity of 400 kifs, while the tast frame was rated at about 200 kips. The jack had been pre-calibrated for correspondence between gage pressure ard applied load.

Load values which are given in the results are values taken fron the jack calibration charts. A separate load transducer was not used, due tc the demonstrative nature of the tests. Load values given are probably within t5 percent and depend primarily on the accuracy of reading jack gage pressure. At the beginning of the test, the gasoline engine for the hydraulic pump was started. A valve was used to control the hydraulic pressure increase. Loads were applied in $10 \mathrm{kip}$ increments to $30 \mathrm{kips}$. This represented approximately a working load range for the member. Agglied load was then released, new zero readings taken, and the load was reapplied in 
10 kip increments. After a load of $70 \mathrm{kips}$ had been reached, the load was again released to zero. A third loading stage then was carried to failure.

\section{Test Results}

Information obtained during the test consisted of vertical deflections, number and spacing of cracks, crack width, and the overall failure pattern.

Vertical deflections were measured at the centerline and quarterpoints of the span using a surveyor s level. Short pieces of level rod were attacised to the beam at the deflection points. Readings were taken at each load level with an accuracy of 0.005 feet or about $1 / 16$ inch. Deflections at the quarter points were essentially symmetrical and an average value of these readings is used on the accompanying plots。 Figure 4 gives the load-deflection response of the bean.

The nember exhibited two basically linear load deflection ranges - one below 30 kips and a second region of reduced stiffness above about 40 kips.

Cracking of the beam under load was corfined to an extremely localized region at the splice. In fact, a single creck at one edge of the grout interface was the only visible crack until just prior to failure, when two cracks formed a few inches on either side of the splice.

Cracking first appeared at a load of 20 kips and was of hairline width. At 30 kips the crack had progressed to approximately the mid-depth of the web. As the applied load increased and the crack width became significant, the width was measured with a hand rule to the nearest $1 / 16$ inch. Figure 5 shows the load-crack width relation observed in the test.

Preliminary calculations by the Bridge Design Section indicated a failure load of 110 kips with a completely bonded cable. Failure load for an unbonded cable was calculated at 59 kips, using a formula for steel stress at 


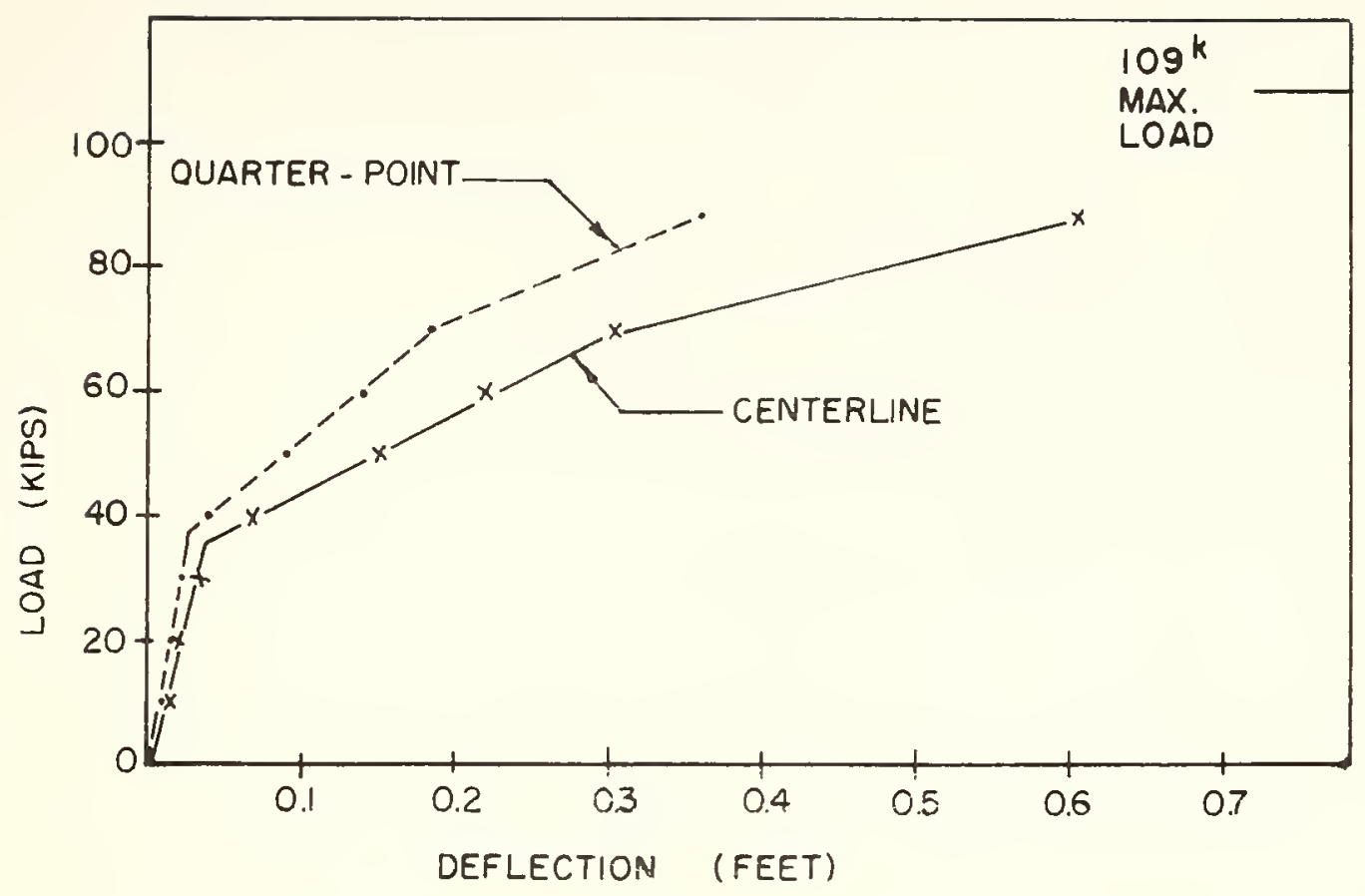

FIGURE 4. POST-TENSIONED SPLICE - LOAD VS. DEFLECTION

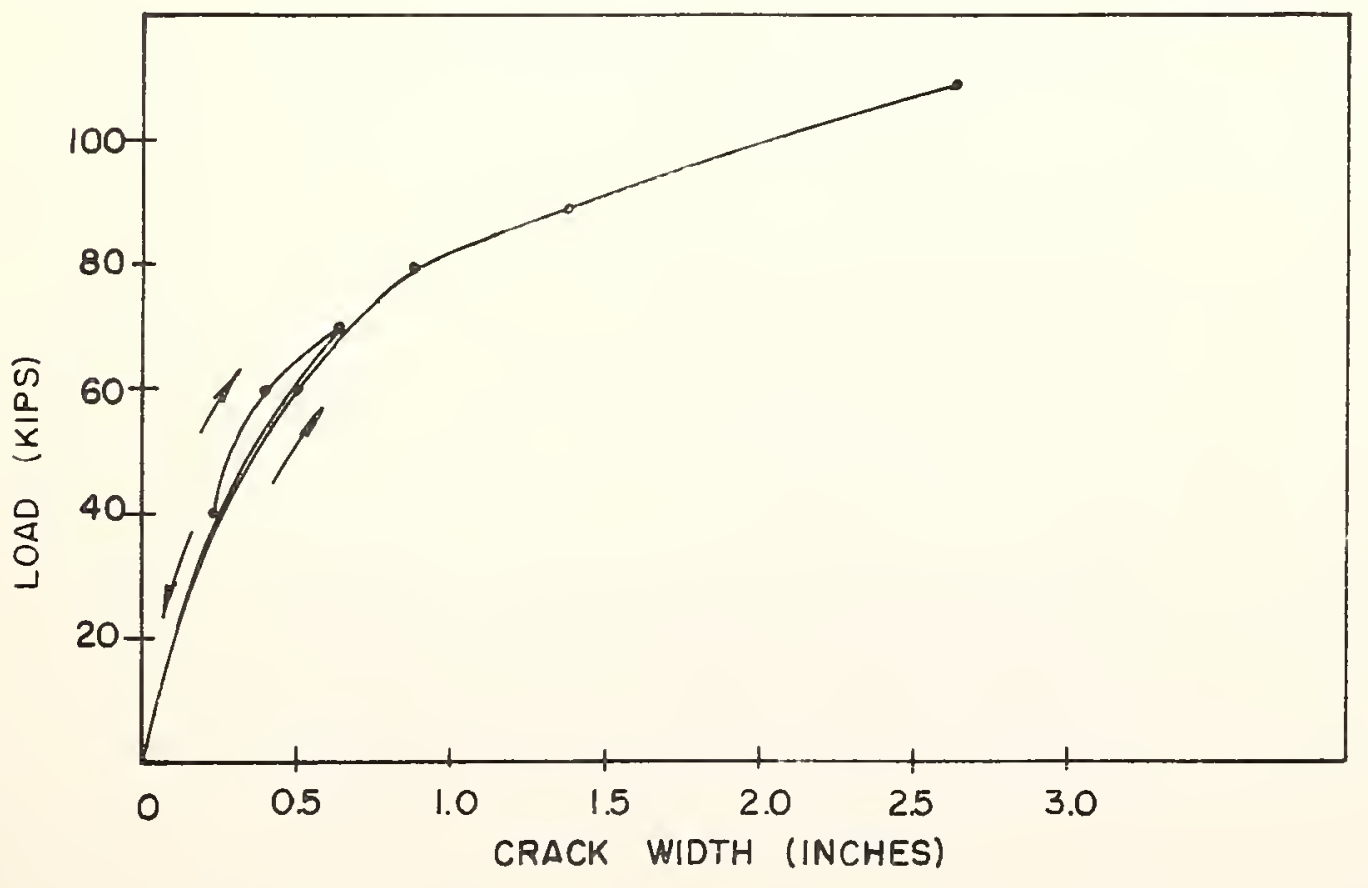

FIGURE 5. POST-TENSIONED SPLICE - LOAD VS. CRACK WIDTH 
failure from the American Association of State Highway Officials (AASHO) design specifications. This fcrmula is extremely conservative and represents a lower load limit on observed failures with unbonded tendons.

Actual failure of the beam came at a load of 109 kips. The beam would not accept greater load and deflected until the jack reached maximum extension. During this time the crack widened on the tension side and gradual progressive crushing of the concrete occurred on the top fibers. Deflection of about 0.6 foot at the centerline was obtained and crack width was about $25 / 8$ inches. Figure 6 shows an elevation view of the spice region of the beam at failure, while Figure 7 is a close ur view of tre splice itself. A portion of the grout layer separated completely from the beam and dropped out.

\section{Discussion of Results}

Results of this splice test were somewhat clouded by the relatively poor grout strengths which were obtained. The grout layer between adjoining beams apparentiy did not cure to a strength or stiffness comparable to the beam and slab concrete, as evidenced by the slab cracking whict cccurred. It is certain that this deficiency could be easily corrected with froper grout design。

A more serious drawback to the post-tensioned splice was the lack cf adequate bond between the cables and the beam. Casting two beams separately and joining them in a region of maximu bending monent autcmatically creates a weakened plane where cracks may be expected. With insufficient bond between the cable and beam, the cable elongations tend to be concentrated at the splice point - resuiting in a large crack width, as evidenced in this test.

It might be argued that improved tendon grouting (and therefore improved bond) world automatically aileviate the crack width problem by distributing the cracks along the member and reducing the average width. The present test can neither confirm nor disprove that supposition. The results cf the 


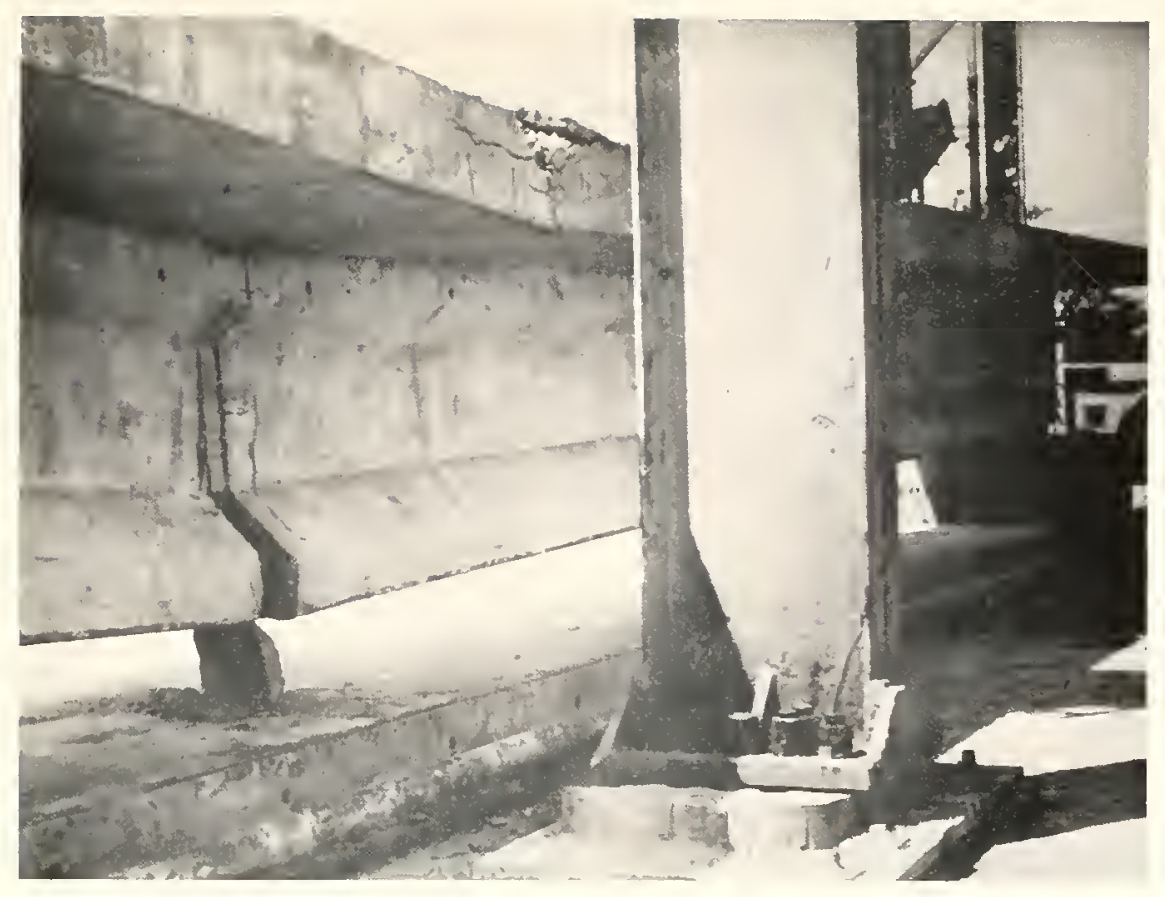

FIGURE 6. ELEVATION VIEW OF POST-TENSIONED SPLICE AT FAILURE

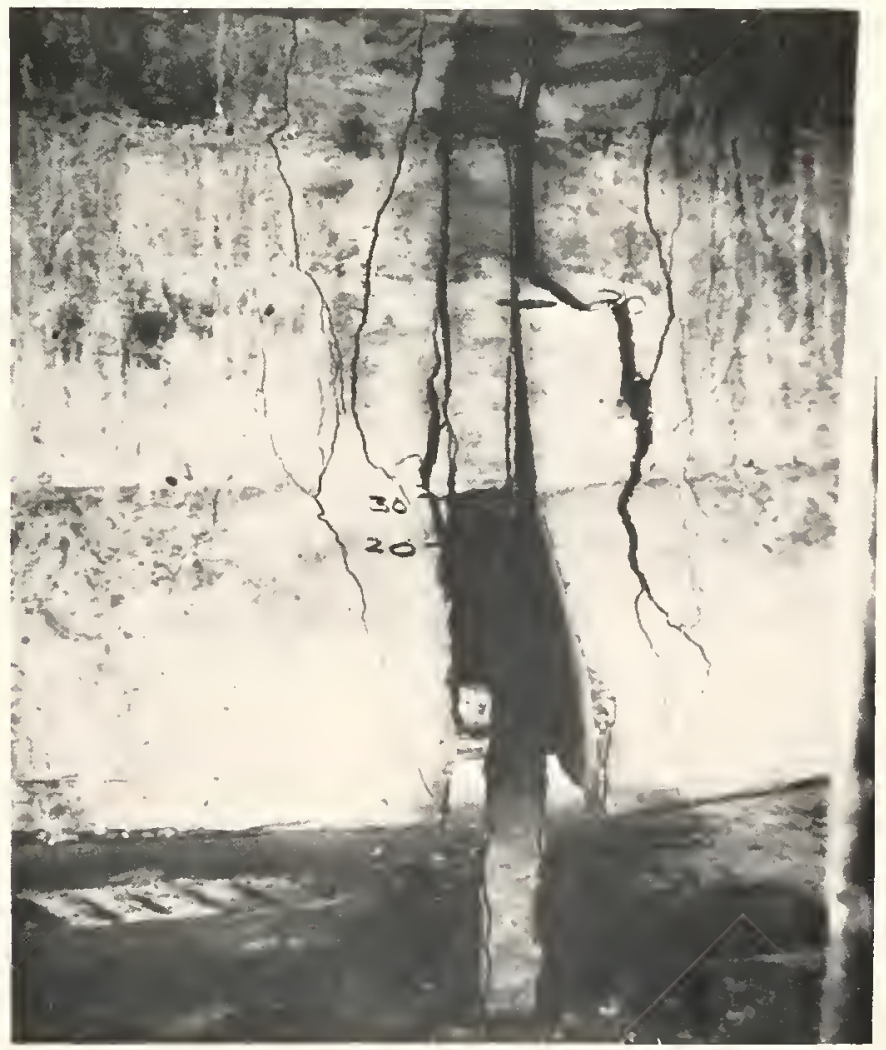

FIGURE 7. CLOSEUP VIEW OF POST-TENSIONED SPLICE AT FAILURE 
present test indicate that excessive crack width at working loads can occur with the splice as constructed.

Another factor to be considered in evaluating tests of this type is that the test inyolved only a few load cycles. Progressive loss of bond due to repeated loading in a highway bridge could also cause excessive crack widths。

The ultimate lcad capacity of the member combared very closely to the predicted value (109 kips vs。110 kigs). The prediction was made using the AASHO equation for bonded steel stress at failure. It should not be implied from this close agreement that the cables were bonded at failure. Examination of Figures 6 and 7 shows the magnitude of slip which had to occur prior to failure. A more reascrable interpretation of the failure load data is that the beam properties were such that large steel elcngations were present at failure. The average steel strain at failure was therefore high and the failure load approached the bonded yalue.

\section{Conclusions:}

Based on the test described above, it appears that the post tensioned splice should nct be used in regions of high bending moment where excessive crack width at working loads is a design consideration.

Further tests might establish that proper cable grcuting would solve the crack width problem by creating better crack distribution.

\section{CAST-IN-PLACE SPLICE}

\section{Backgrourd}

Construction of continuous spans by splicing several units is very often dore by placing the splice rear a point of inflection, as illustrated in Figure 8. The ccncept may be easily extended to multiple spans. The splice would normally be used in regions of relatively small bending moment, but would be subjected to fairly high shears. 


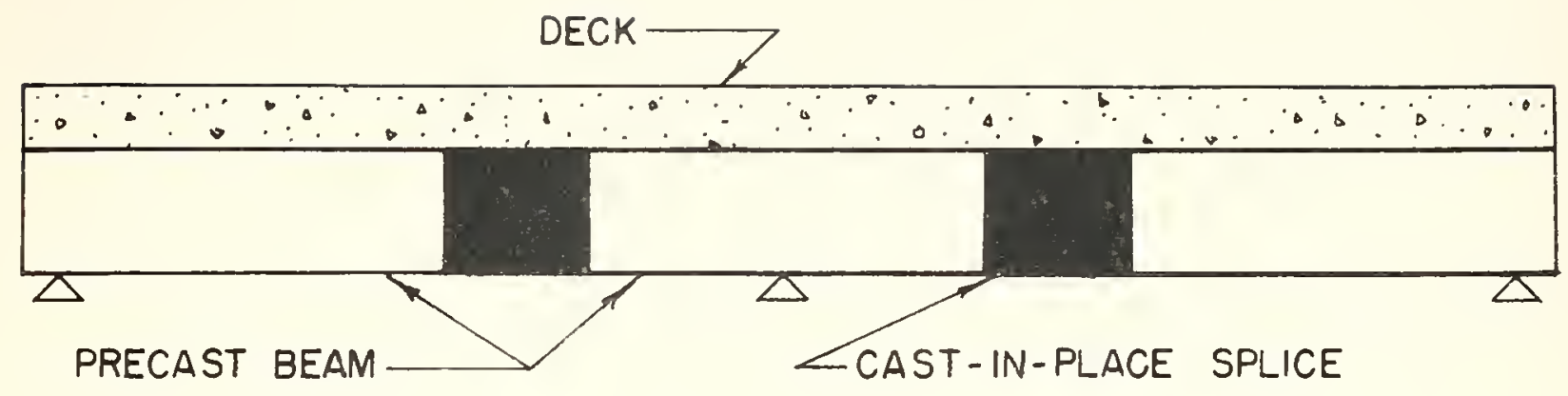

FIGURE 8. CAST-IN-PLACE SPL!CE - GENERAL ARRANGEMENT

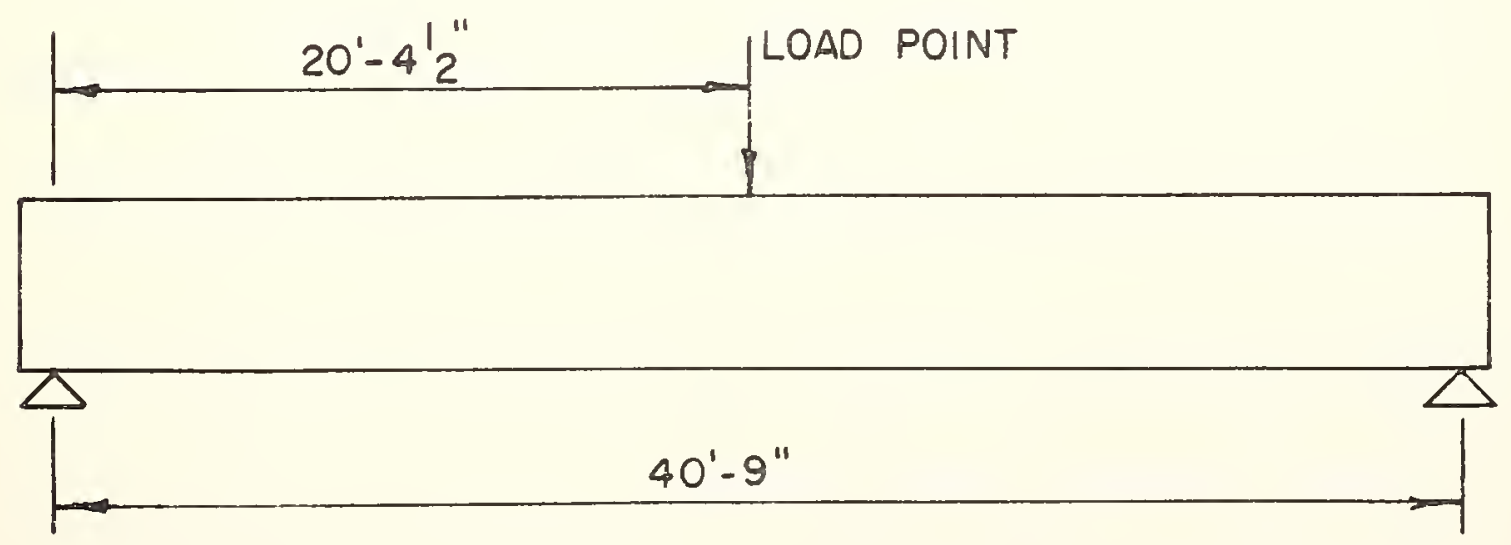

FIGURE 9. CAST-IN-PLACE SPLICE - BEAM ELEVATION 
The splice cortemplated in the present application consists of a cast-inplace concrete section of perhaps 4 feet in length, reinforced with mild steel bars projecting from each precast element. Supplemental stirrups are also used in the splice. (Possible variaticns would include post-tensioning the cast-in-place portion, but this will not be considered herein.)

If this type of splice is placed near a dead-ioad point of inflection, one design condition of importance would be the possibility of live load causing splice moments of differing sense. If certain positions of live load cause tension on the top and other fositions cause tension on the botton, the need for splice steel cr both faces should be considered. The splice described herein was reinforced on one side only.

Construction of the splice in the field would entail supporting the precast units on temporary shores, forming and pouring the splice, and finaliy casting the deck slab.

\section{Details of Test Ream}

The test specimen had an overall length of $43^{\circ}-0^{\prime \prime}$. Loading arrangement and spar length are shown in Figure 9. The cast-in-place splice was placed near the quarter-point of the span. Figures 10 and 11 show the details of the precast beam. Figure 12 shows the details of the cast-in-place joint.

The member was tested as a simgle beam having a spar length of $40^{\circ}-9^{\prime \prime}$, with a concentrated load at the center of the span. The loading arrangement caused high shear at the splice, along with a relatively high bending moment while this condition would rarely occur in field usage, it is certainly a more stringent test of the splice. Thus, a large amount of mild steel was placed in the splice to carry the anticipated bending moment. Electric strain gages were placed on the mild steel bars at locations shown in Figure 13 . 


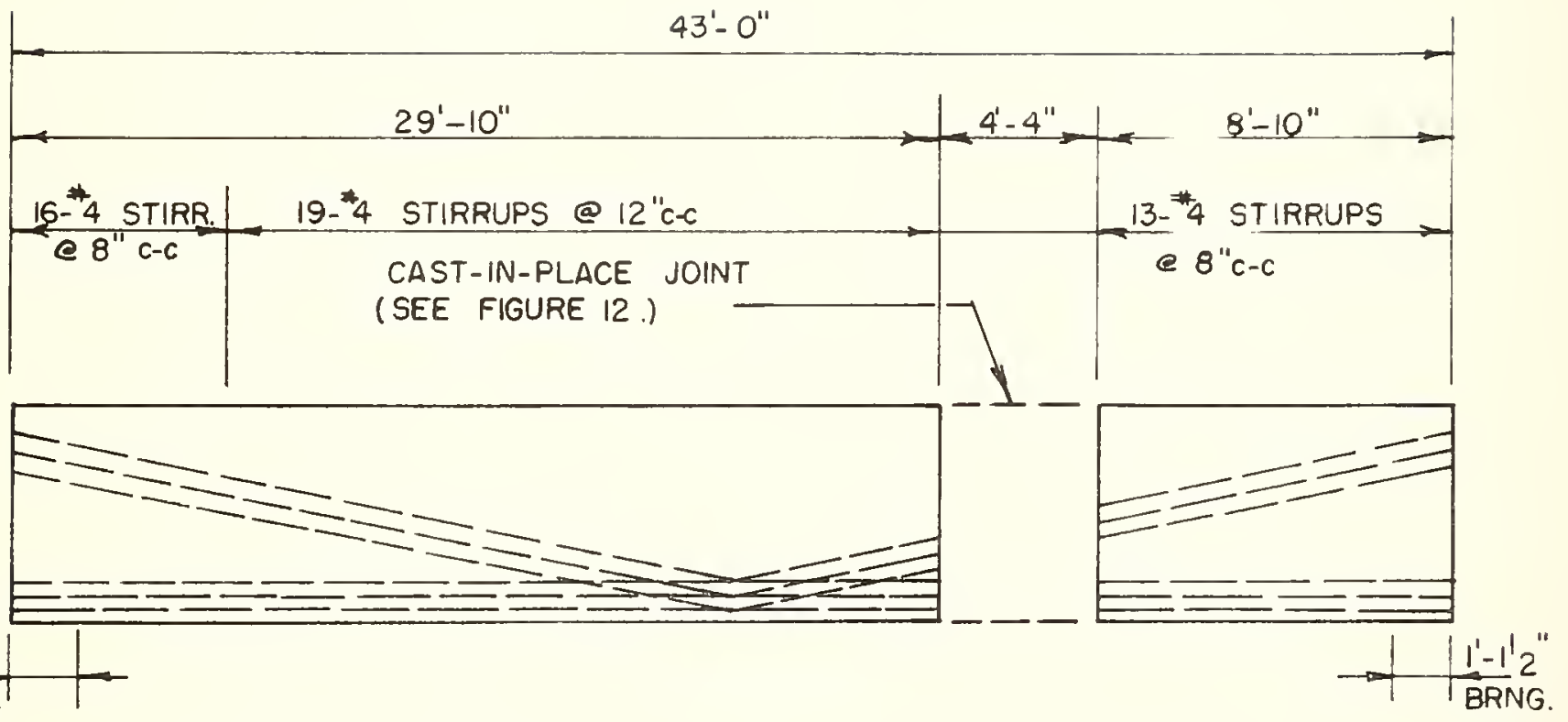

FIGURE 10. CAST-IN-PLACE SPLICE - BEAM ELEVATION 


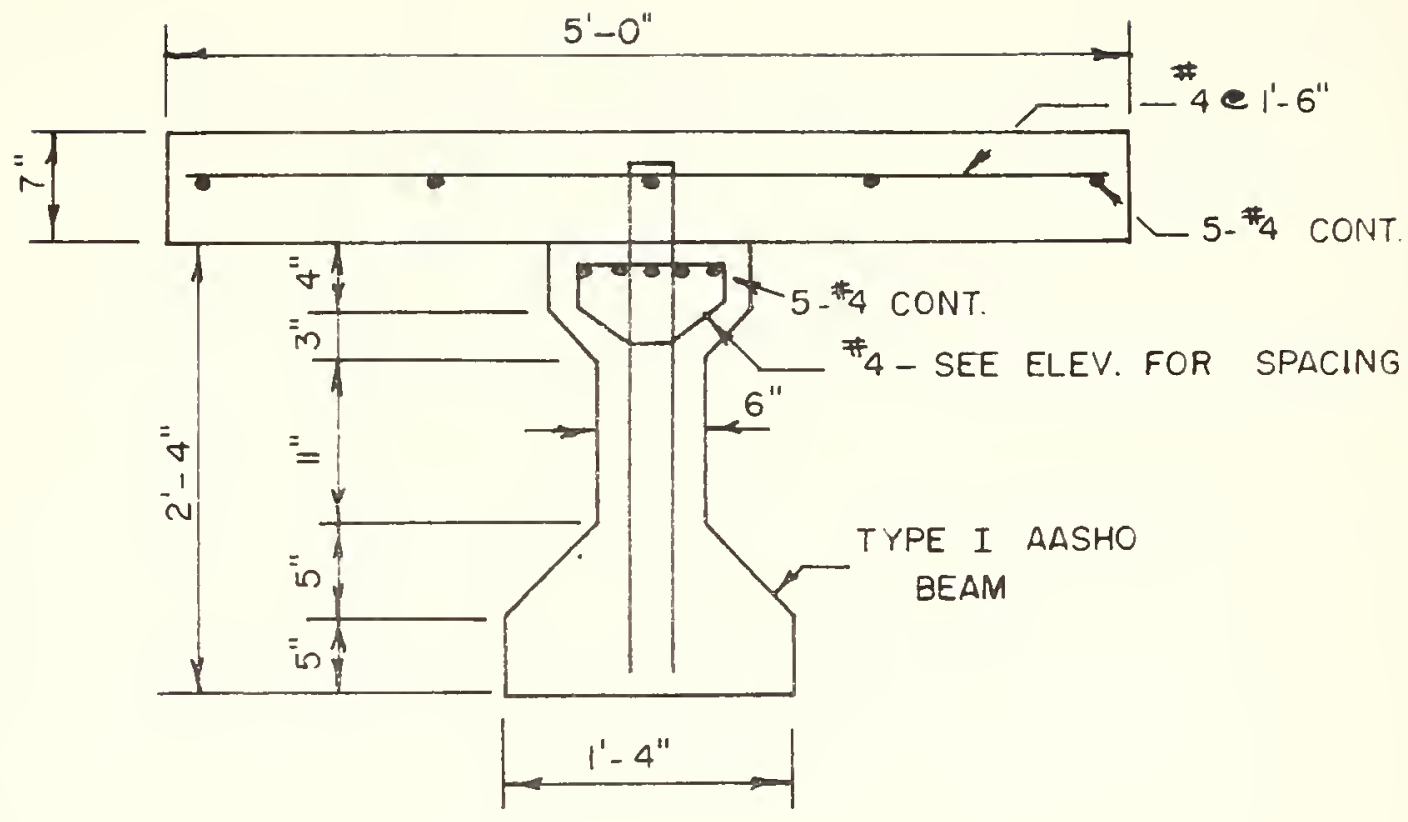

(A) SECTION

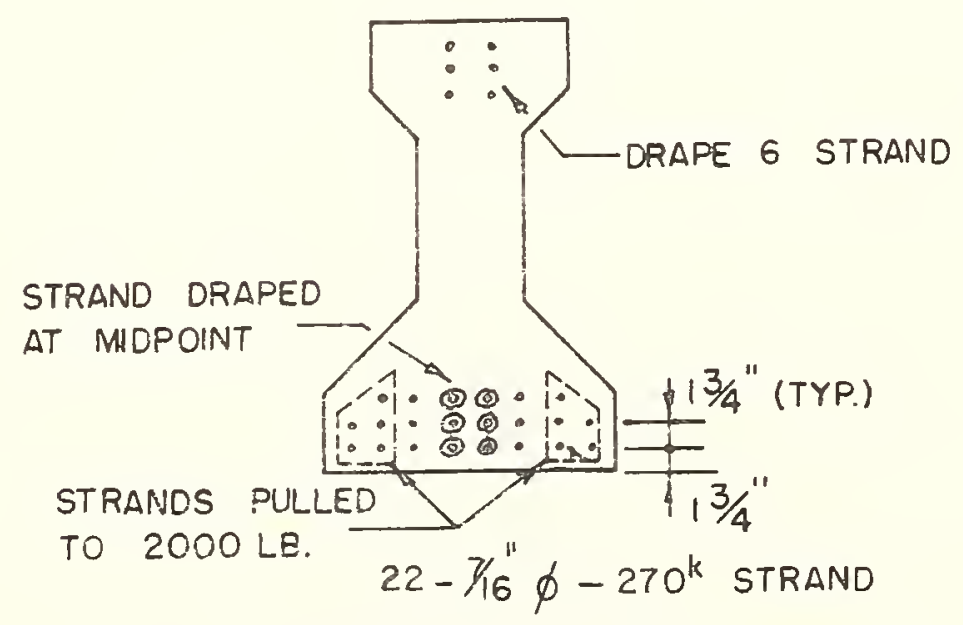

(B) STRAND PATTERN

FIGURE II. CAST-IN-PLACE SPLICE - BEAM SECTION 


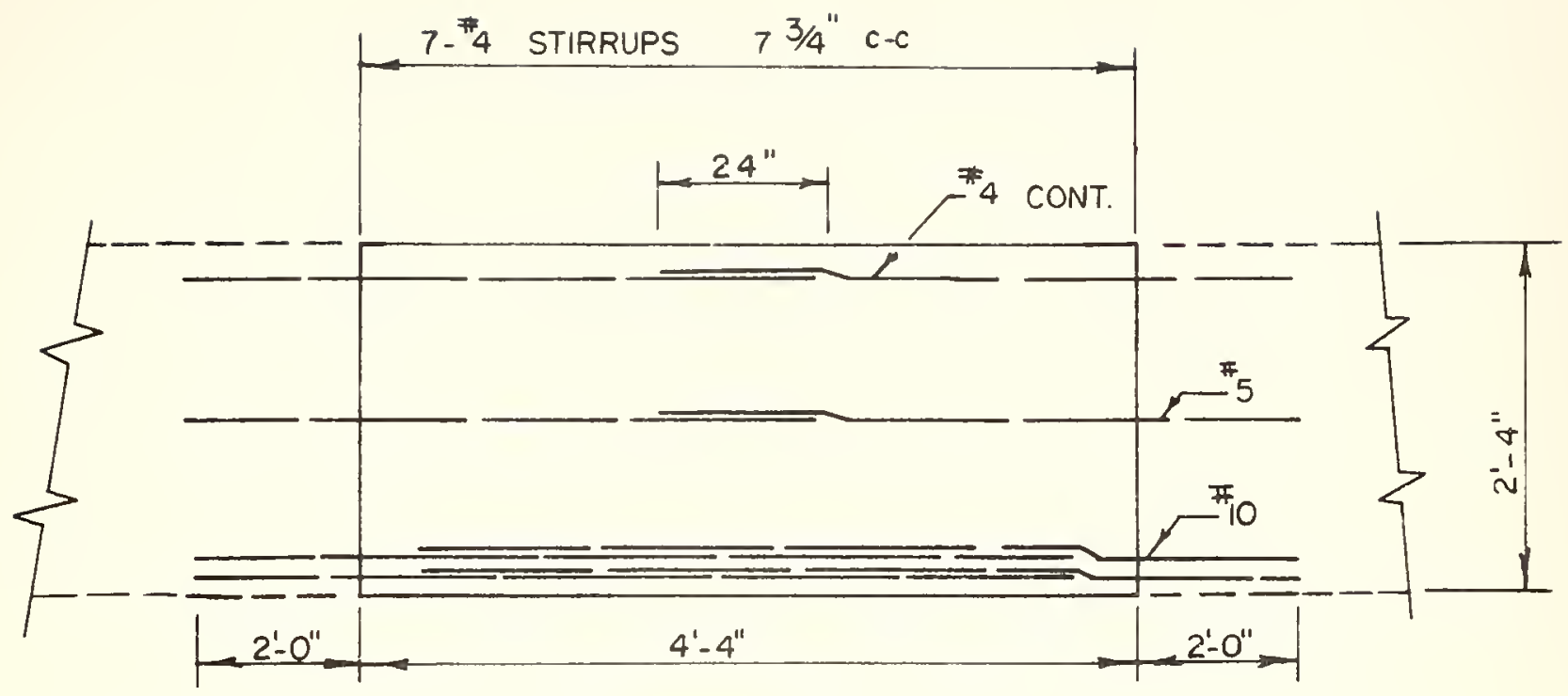

(A) ELEVATION

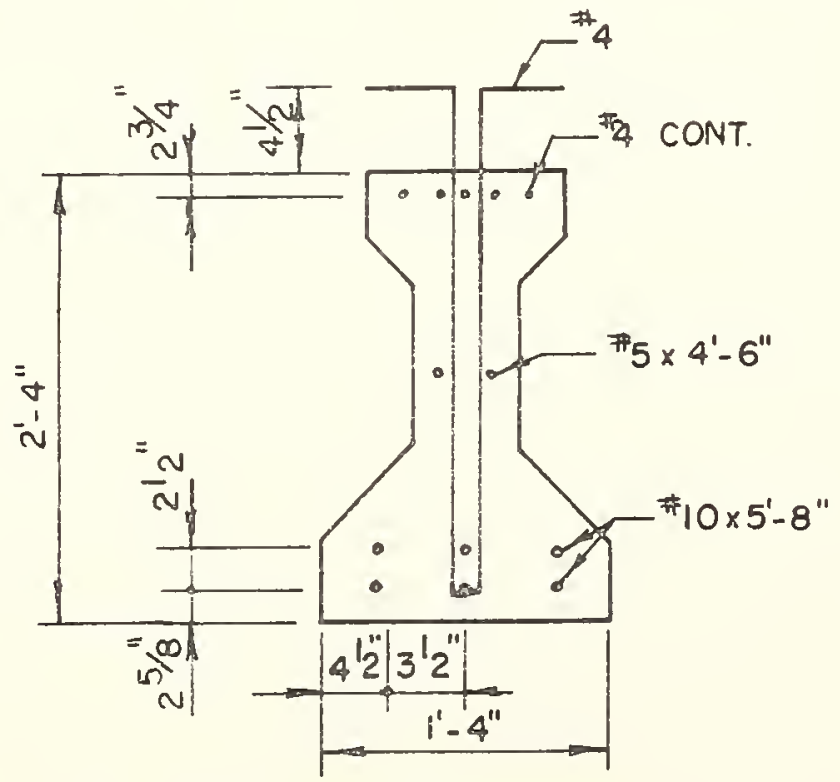

(B) JOINT CROSS SECTION

FIGURE 12. CAST-IN-PLACE JOINT DETAILS 
Construction of the test beam was made by forming the precast elements in a prestressing bed and using a blockout in the splice region. Mild steel bars (embedded $2^{n}-0^{\prime \prime}$ into the precast beam) projected through the blockout area. The precast elements were pre-tensioned with straight and deflected cables which ran continuously through the blockout. After curing of the precast elements, the pretensioning cables were cut off at each end of the precast elements. The remainder of the selice reinforcement was then placed. Beams were cast on April 24 and the splice was placed on April 29. Siab concrete was placed on April 30. The member was tested on May 15.

Iable 2 gives the cylinder compressive strengths obtained for the concrete used in the various pours.

Table 2. Concrete Cylinder Strengths - Cast-in-Place Splice

\begin{tabular}{|l|c|c|c|}
\hline \multirow{2}{*}{ Member } & 6" x 12" Cy1 inder comeressive strength \\
\cline { 2 - 4 } & 1 day & 7 days & 28 days \\
\hline \multirow{2}{*}{ Beam } & $4630 \mathrm{psi}$ & $6160 \mathrm{psi}$ & $7030 \mathrm{psi}$ \\
Splice & $5060 \mathrm{psi}$ & $6190 \mathrm{psi}$ & $5960 \mathrm{psi}$ \\
Slab & $4250 \mathrm{psi}$ & $5100 \mathrm{psi}$ & $5690 \mathrm{psi}$ \\
\hline
\end{tabular}

* Average of three cylinders

An epoxy bonding compound was specified on the ends of the precast elements to facilitate bond between the beam and solice ccncrete. Frior to the beginning of the test, a hairline crack was observed at each end of the joint concrete over the entire depth of the nember. These were apparently shrinkage cracks.

\section{Test Procedure}

The specimen was loaded with the hydraulic jack and loading frame described previously. Elastomeric pads were provided at the end bearings and at the load point. 
Loading was applied in $20 \mathrm{kig}$ increments, up to $60 \mathrm{kips,}$, fiter which 10 kip increments were used. An unloading cycle was not used.

Frovisions were made to measure the strains at several points on the mild steel in the splice. Tertical deflections were measured, and the cracking pattern and failure behavior were observed.

\section{Test Results}

Sixteen metal film strain gages were attached to the mild steel splice bars in pairs at the points indicated in Figure 13. Gage reference numbers are also designated ir the figure. The gages were temperature compensated for steel. A dummy gage on $a$ steel bar embedded in a concrete cylinder was used; three-wire leads to each gage minimized temperature effects due to the lead wire lengths. Gages were waterprocfed with an epoxy compound and a technigue which disturbed only a small portion of the bond surface of the bar.

Gage number 16 was not oceratige at the start of the test and gage number 11 was damaged during the test. Strains in the remaining gages were measured at various load levels using a Budd Type $\mathbf{E}-350$ portable batteryoperated strain indicator. Reading accuracy was $t_{5}$ micro-inches per incin.

The strain data obtained are given in Tabis 3 . Figure 14 is a glot of load versus steel strain for the various gages. Each gage strain plotted is the average of two gages at the same location, one each on the top and bottom of the bar. Thus gages 1 and 2 are averaged, as are 3 and 4 , ete. 


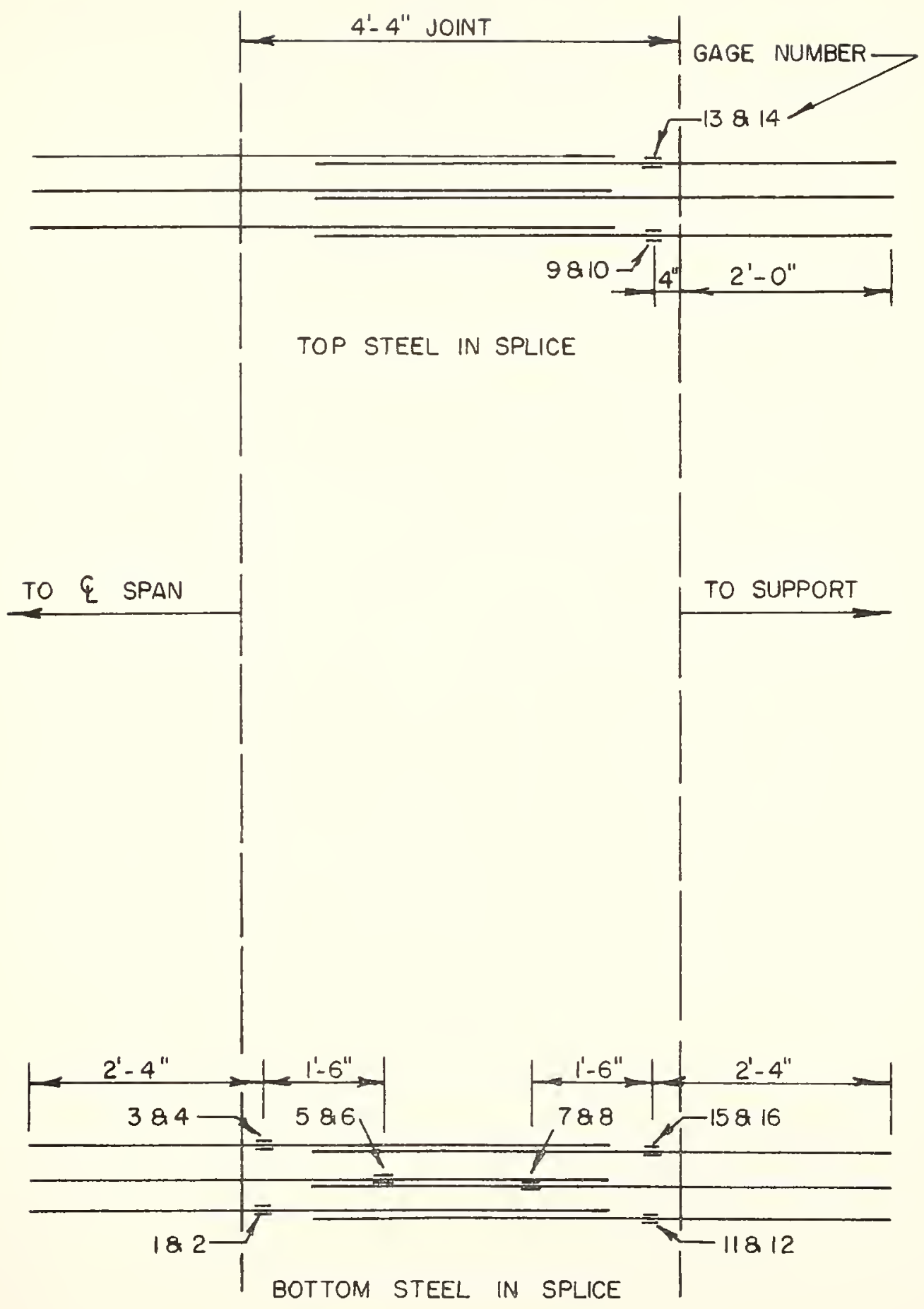

FIGURE 13. CAST-IN-PLACE JOINT - STRAIN GAGE LOCATIONS 


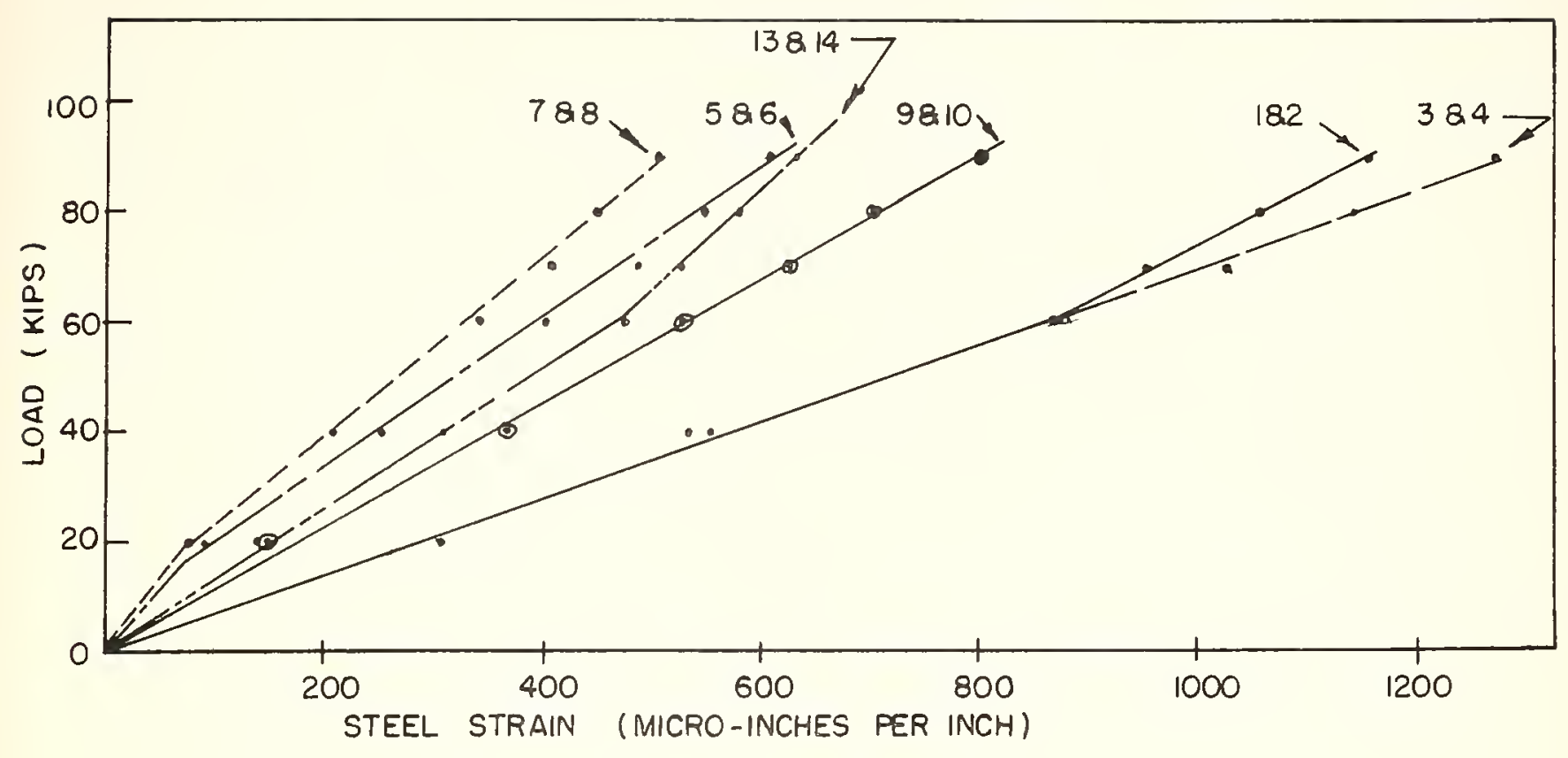

FIGURE 14. CAST-IN-PLACE SPLICE - LOAD VS. STEEL STRAINS

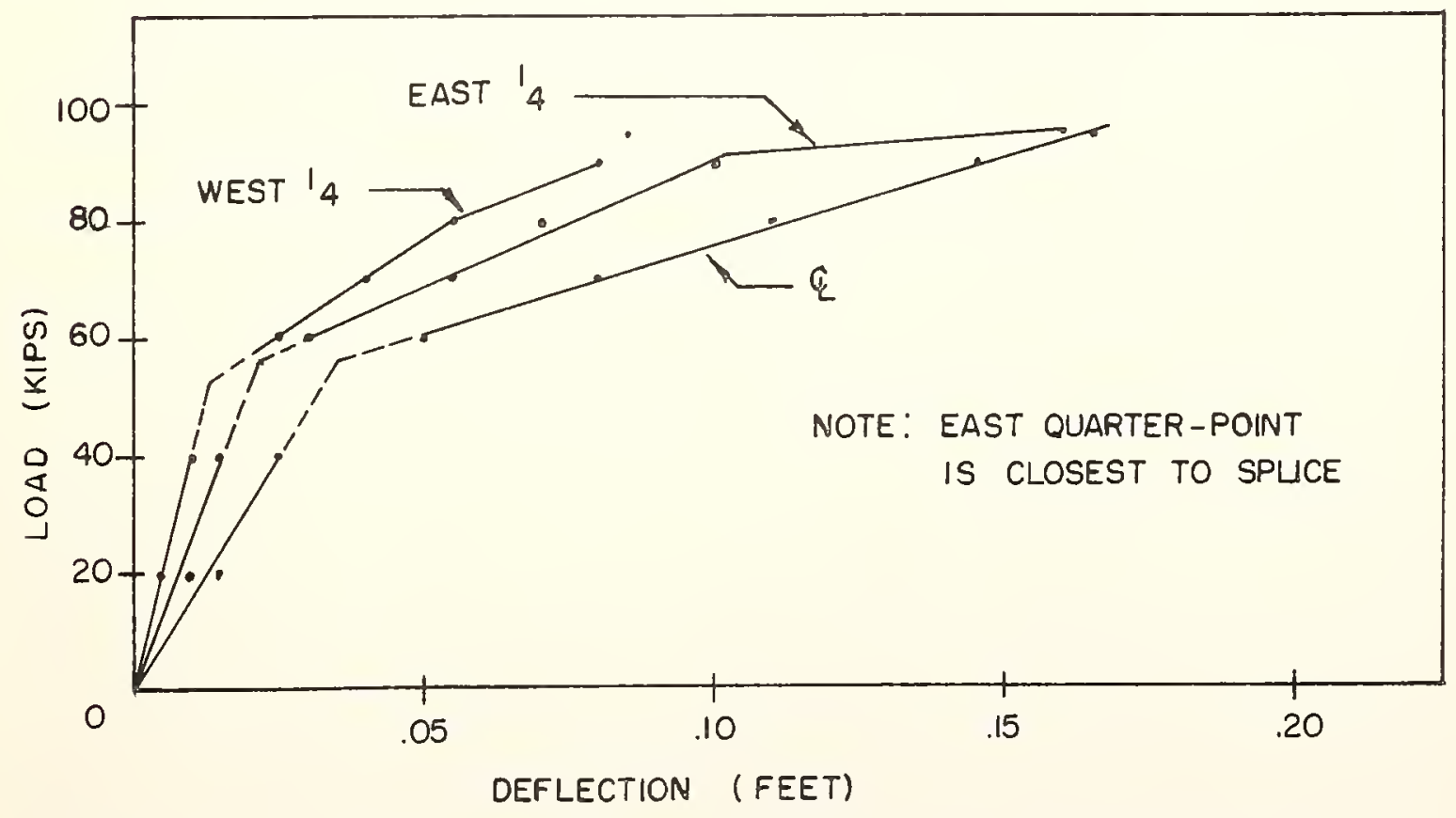

FIGURE 15. CAST-IN-PLACE SPLICE - LOAD VS. DEFLECTION 
Table 3. Steel Strains for

Cast-iñ-Place Splice

\begin{tabular}{|c|c|c|c|c|c|c|}
\hline \multirow{2}{*}{$\begin{array}{l}\text { Gage } \\
\text { Numbert }\end{array}$} & \multicolumn{6}{|c|}{ Load (kizs) } \\
\hline & 20 & 40 & 60 & 70 & 80 & 90 \\
\hline 1 & 296 & 508 & 734 & 848 & 928 & 1002 \\
\hline 2 & 322 & 558 & 986 & 1060 & 1192 & 1312 \\
\hline 3 & 318 & 576 & 924 & 1110 & 1262 & 1448 \\
\hline 4 & 294 & 556 & 838 & 942 & 1022 & 1092 \\
\hline 5 & 88 & 246 & 370 & 440 & 492 & 554 \\
\hline 6 & 90 & 264 & 440 & 530 & 598 & 670 \\
\hline 7 & 68 & 208 & 342 & 400 & 430 & 482 \\
\hline 8 & 90 & 210 & 342 & 420 & 470 & 532 \\
\hline 9 & 162 & 364 & 518 & $6: 6$ & 688 & 782 \\
\hline 10 & 136 & 364 & 542 & 638 & 718 & 822 \\
\hline 11 & 128 & 368 & 636 & $\cdots$ & $\cdots$ & $\cdots-$ \\
\hline 12 & 142 & 344 & 490 & 606 & 680 & 752 \\
\hline 13 & 128 & 308 & 504 & 554 & 620 & 678 \\
\hline 14 & 152 & 312 & 442 & 492 & 542 & 584 \\
\hline 15 & 172 & 348 & 510 & 692 & 778 & 854 \\
\hline
\end{tabular}

See Figure 13 for gage location 
Beam deflections were measured at the centerline of span and the quarterpoints using small lengths of surveyor"s rod attached to the beam at these points. A surveyor's level was used and the deflections were raad to 0.005 feet accuracy. Readings were also taken on the end bearings to determine the deflection of the elastomeric pads. The pad defiections were quite small and were subtracted from the indicated beam deflections to give the true bean deflections.

Figure 15 is a plot of the load-deflection relation obtained at each point Results at the two quarter-foints were significantly different and are plotted separateiy. The deflection curves are shown dashed in the vicinity of the cracking load. This is an idealization of the member behavior, since no measured data were obtained in this load range. The splice is located acproximately at the east quarter-point.

The first cracks due to loading occured in the splice region at a load of 40 kips. Four cracks appeared, at a spacing of about 16 inches. The cracks extended to the junction of the web and upper flange. Figure 16 is a picture of the splice region at this stage of loading. Note that the cracks were traced with a felt marking pen to indicate their position; the actual crack width is very small。

During the next load increment, from $40 \mathrm{kips}$ to $60 \mathrm{kips}$, cracks formed in the precast element near the center of the span. These cracks extended to the top of the web. Load increments of 10 kips were then applied until the beam failed. Cracking developed extensively between 60 and $90 \mathrm{kips}$. At a load of $70 \mathrm{kips}$ an inclined crack formed in the splice, but peretrated only slightly above the center of the web. Crack width at this stage of loading was of the order of 0.01 inches.

At a load of 90 kips there were several diagonal cracks in the end of the precast beam adjacent to the splice (between the load point and the splice). 


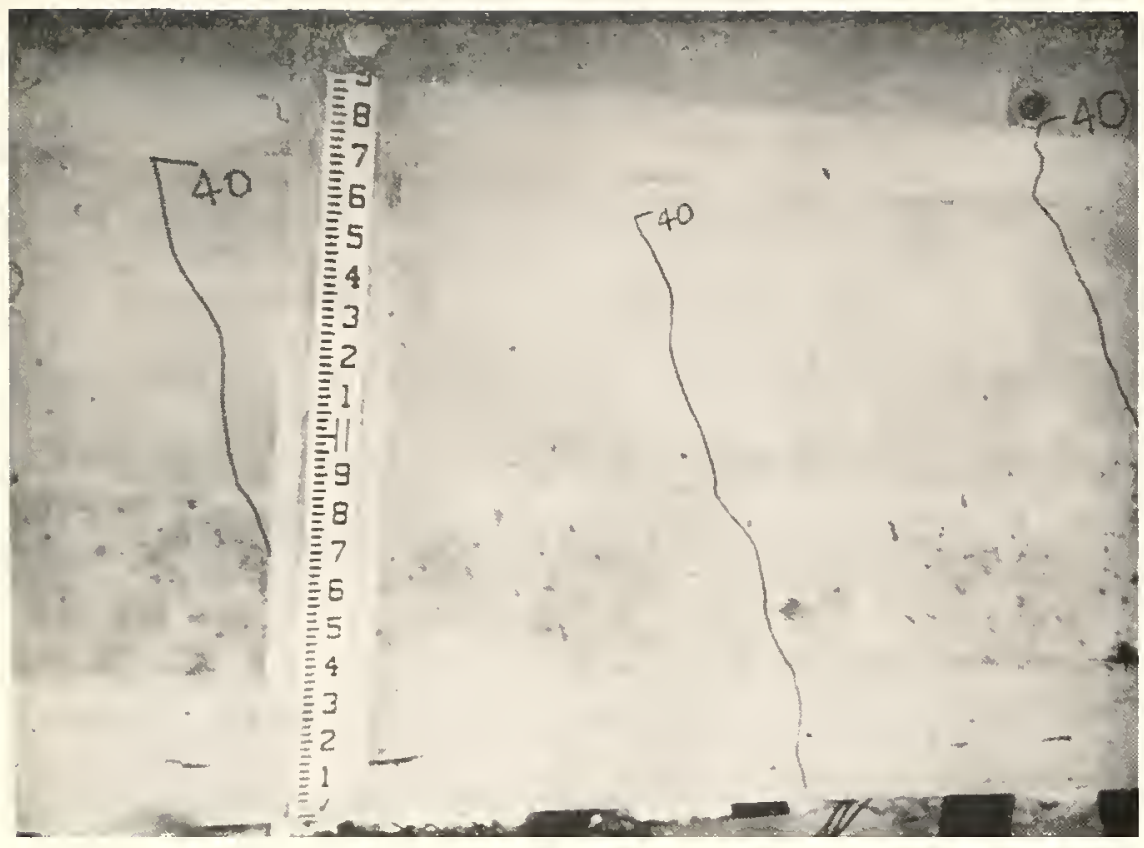

FIGURE 16. CAST-IN-PLACE JOINT AT CRACKING LOAD

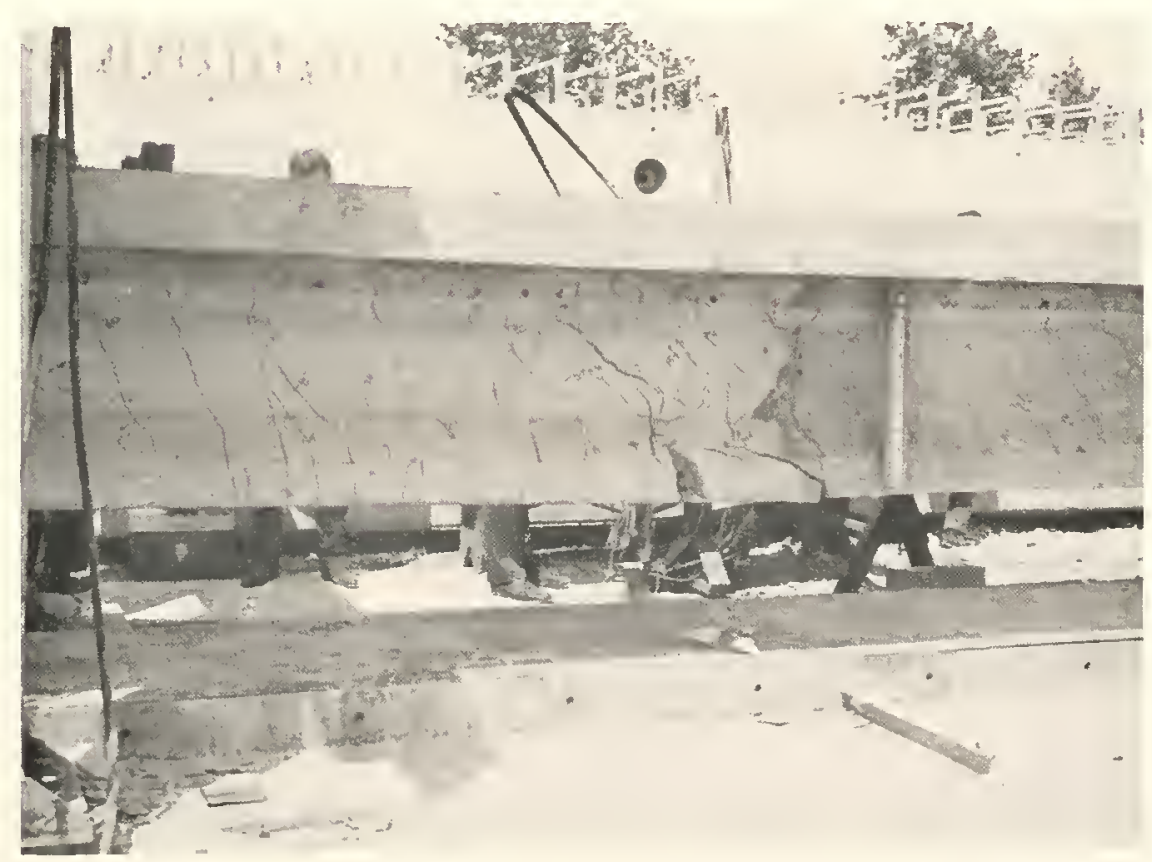

FIGURE 17. CAST-IN-PLACE SPLICE AT FAILURE 
Web distress was rather evident in this region of the precast beam at 90 kips。

The member failed at a load of $96 \mathrm{kips}$ during the next load increment Failure was sudden and with little warnirg. The diagonal cracks in the precast portion extended through the bottom flange and widened considerably. Figure 17 is a close-up of the failed region, with the splice at the right and the precast beam on the left. Two major cracks extend from the web cracks-one diagonally through the bottom flange and the other vertically downward。

The splice region was in ro apparent distress at the time of failure A few smali diagonal cracks had formed, but there was little evidence of impending bean failure in the splice. In other words, it appeared that failure in the splice itself would have occured at a higher load. Figure 18 is a view of the member after failure, showing the extensive cracking which developed in the precast eiement and contrasting this with the splice region.

Discussion of Resilts

Irior to the test, the failure load of the member was predicted to be 125 kips, caused by yielding of the splice steel. Actual failure load was 96 kips and the failure mode was diagonal tension in the prestressed member near the splice. Differences between predicted and measured performance are due to the fact that the precast beam adjacent to the splice was not analyzed critically. It was assumed by the designer that the splice would control the failure.

Closer examination of the failure section reveals why the beam failed as it did. The failure region was essentially an anchorage zone for the pretensioning cables and was only partially compressed. The mild steel was embedded on 1 y $2^{\circ}-0^{\prime \prime}$ into the precast member for anchorage. Nominal stirrups 


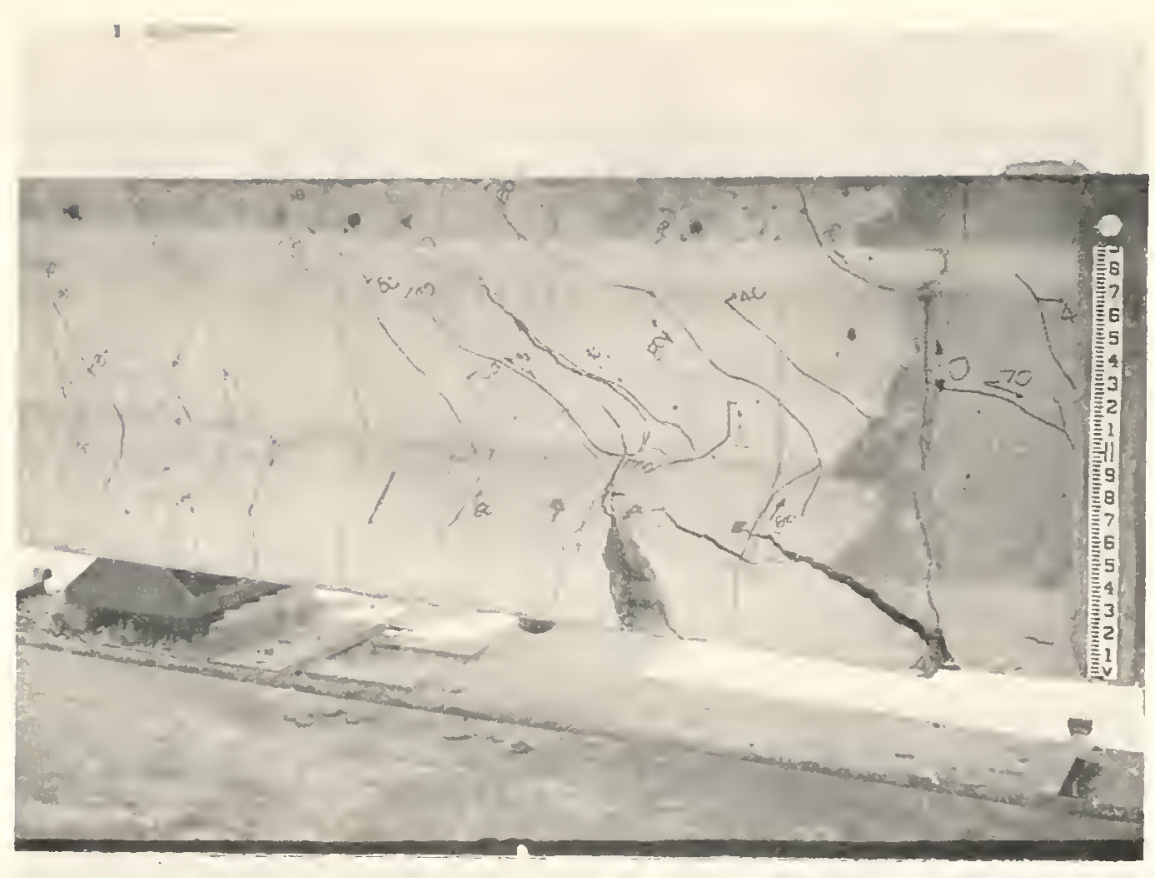

FIGURE 18. CAST-IN-PLACE SPLICE - OVERALL VIEW OF BEAM AT FAILURE

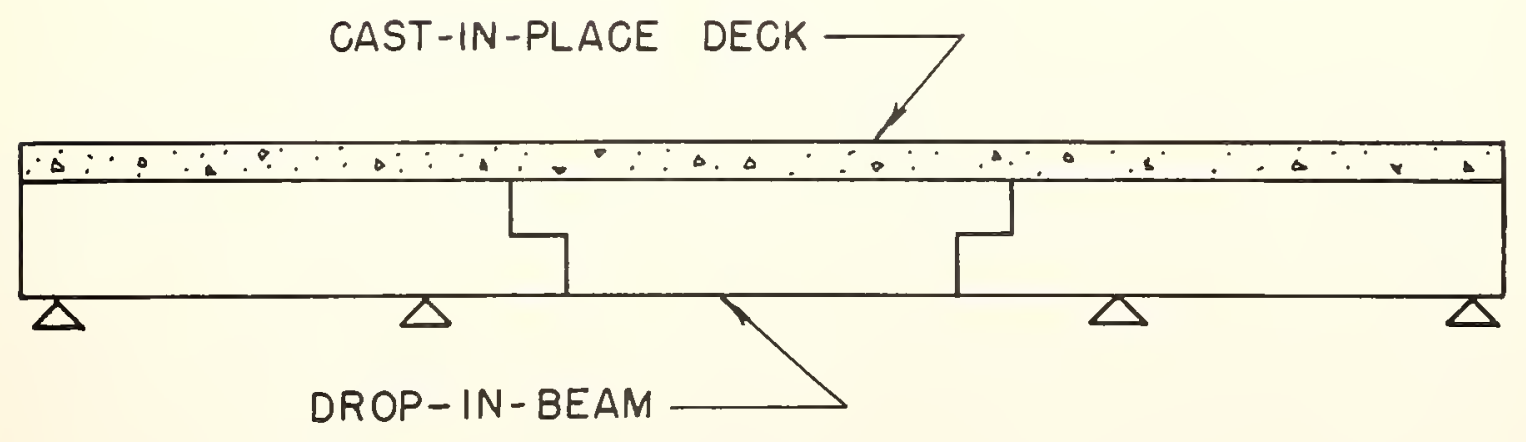

FIGURE 19. DROP - IN - SPLICE - GENERAL ARRANGEMENT 
at 12 inch centers were placed in the failed zone. The shear in the splice region is practically identical to that at the end of the precast beam. Bending moments are larger in the grecast region than in the splice. Reinforcing in the splice region was considerably greater than in the precast beam. Considering these unusual circunstances, the actual stress situation in the end region of the precast section is rather complex to say the least.

Testing of a number of specimens would probably establish the minimum required amounts of reinforcement to prevent prenature failure. In Iieu of further testing, however, recognition of the failure pattern leads to two remedies: placement of additional stirrups in this region of the precast beam, and extension of the splice bars further into the precast member. It should be recalled, also, that this tyge of field splice will probably be subjected to smaller relative bending moments than the test splice.

Strains in the nild steel at the splice were essentially linear. Elastic or straight-1ine theory calculations predicted strains within about $15 \%$ accuracy, indicating rothing unusual occurred in the splice. The beam failed prior to yielding of any of the spilce steel.

Beam deflections indicated two reasonably linear response curves. Beam stiffness decreased markedly at a load of approximately 60 kips. This load corresponds to the initiation of general cracking in the prestressed member. Deflections at the east quarter-point were greater than those at the west quarter-point at every load level. This behavicr is due to the "softer" or non-prestressed concrete at the splice. Deflections at the splice increased rapidly during the load increment which caused failure. 
Cracking of the member was extensive, with numerous cracks of smal1 width present. Diagonal cracking was not important until just prior to failure. The general pattern of cracking was of the type considered desirable. Cracks were well distributed along the span, with few important cracks in the splice itself.

\section{Conclusions}

The overall performance of the cast-in-place splice was adequate. Slight design modifications indicated by the failure behavior should render the splice useful for field applications. Suggested modifications apply to the precast beam end rather than the splice itselfo

\section{III。 DROP-IN SPLICE}

\section{Background}

A drop-in splice of the type illustrated ir Eigure 19 is often used for ease of construction. The joint simply involves placing the drop-in beam on the previously set anchor beams. Dowel rods may be used for alignment or longitudinal shear purposes. An elastomeric pad or cushion may be placed between the bearing facas. The joint is subjected to shear delivered from the supported member.

Instead of testing the complete joint, a concrete member representing one side of the joint was fabricated and tested with a steel bearing shoe used to simulate the supporting beam

\section{Details of Test Beam}

Figure 20 shows the details of the test specimen and its loading arrangement. A steel bearing plate was cast in the member and used in conjunction with a moveable steel bearing shce. The beam was cast on May 12, 1969 and was tested at an age of three days. Cylinder compressive 

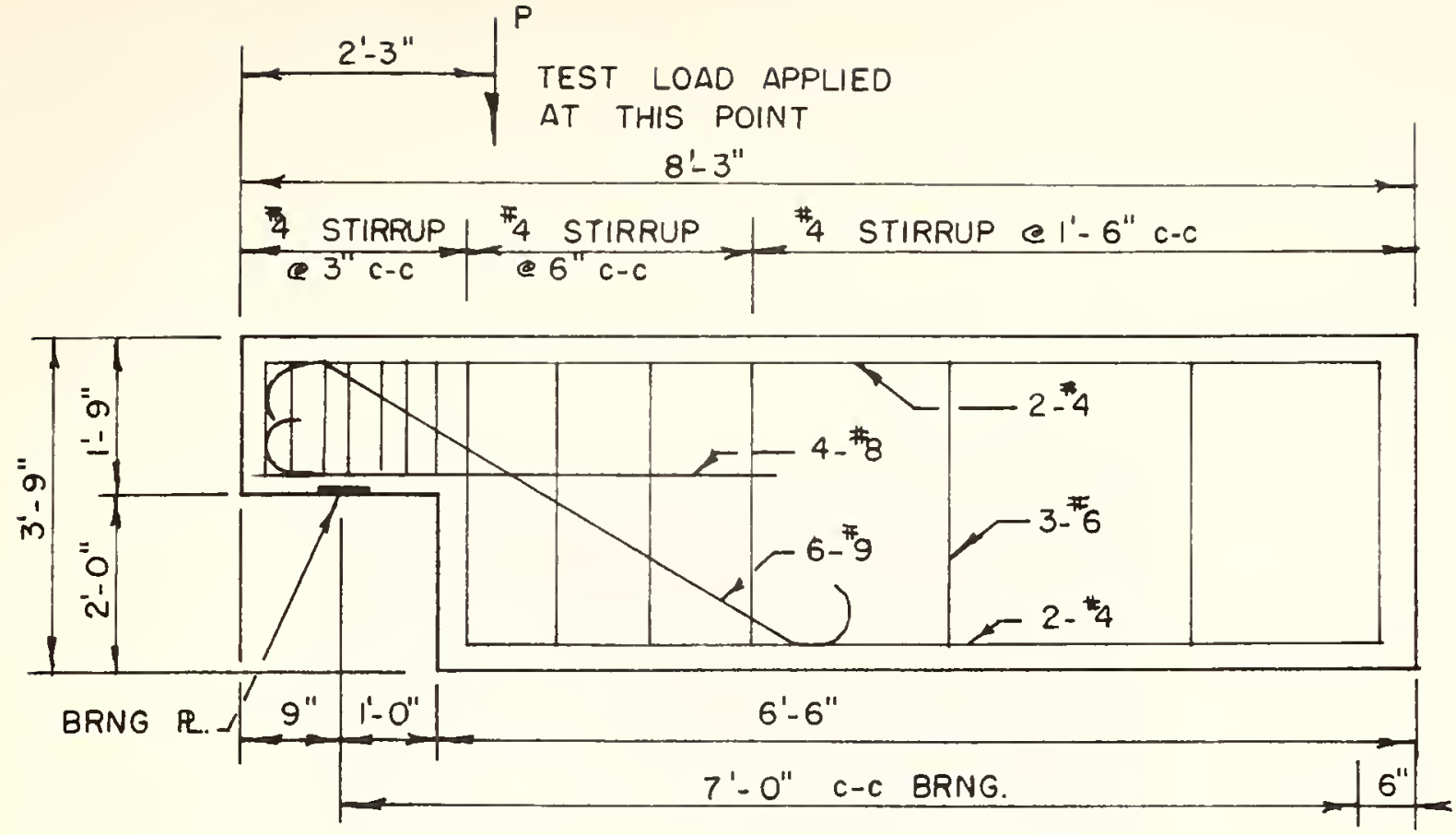

(A) ELEVATION

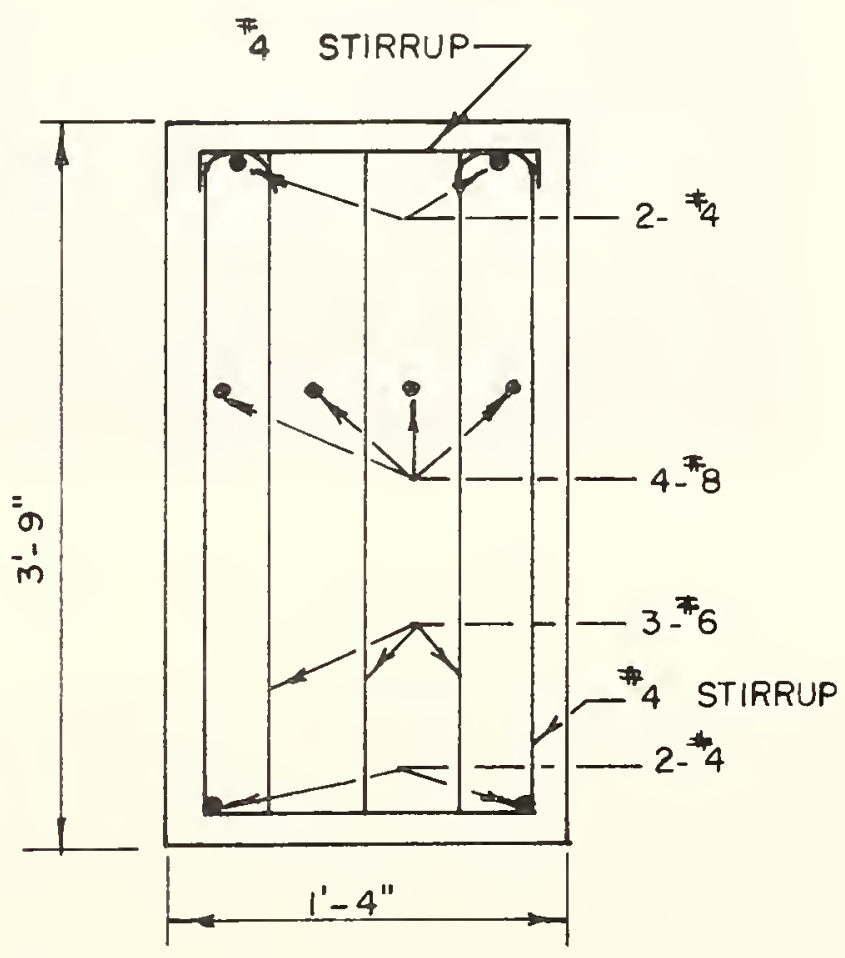

(B) SECTION

FIGURE 2O. DROP-IN SPLICE DETAILS 


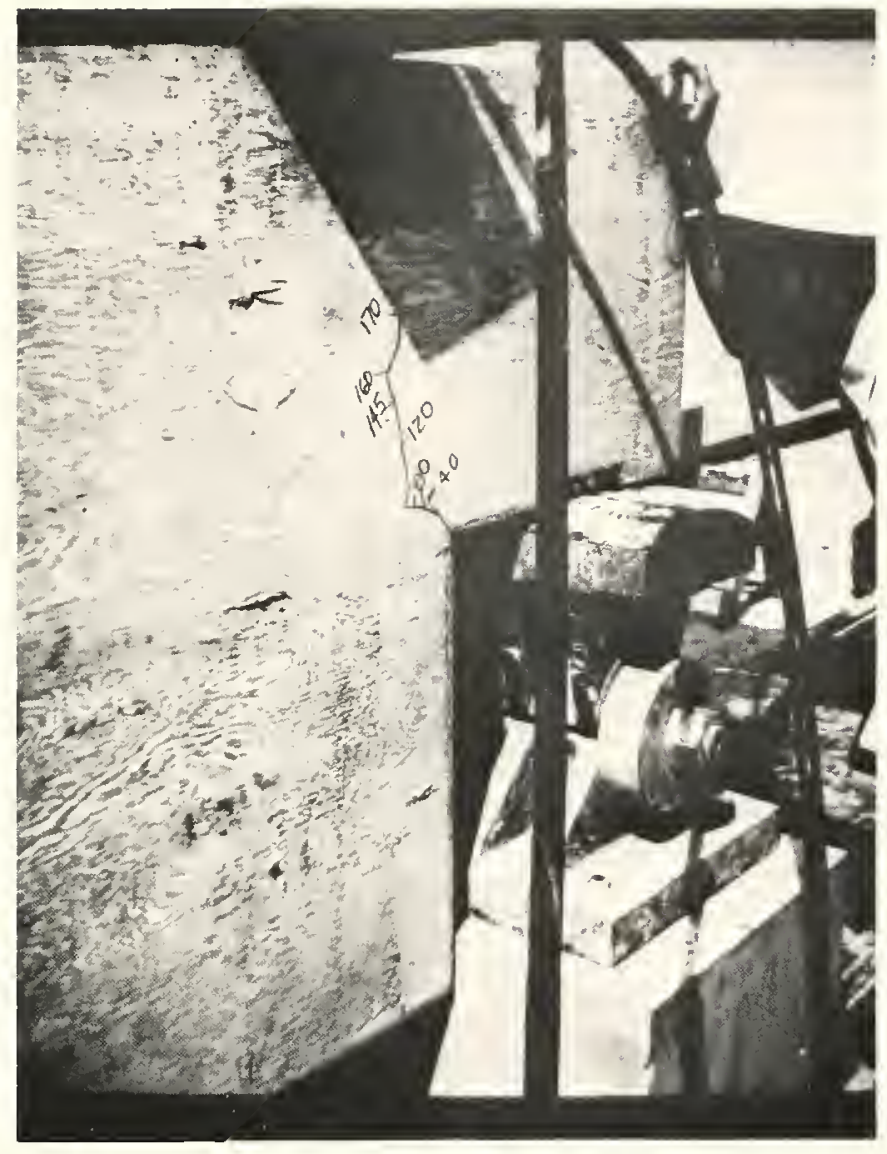

FIGURE 2I. DROP-IN SPLICE AT END OF TEST 
strengths were: 5130 psi at one day, 6190 psi at 7 days and 7170 psi at 28 days. Instrumentation was not used on the specimen.

\section{Test Results \& Discussion}

A photograph of the beam in test positicn is presented as Figure 21 . The load was applied in increments to $170 \mathrm{kips}$. An extremely small crack at the re-entrant corner occurred at a load of $40 \mathrm{kips}$. The crack gradually extended to the position seen in the figure at the end of the test. Crack width was very low at a11 times - measured width was 0.003 inches at a load of 145 kips. The test was halted at the 170 kin load, since this was approaching the useful capacity of the test frame. The joint gave no indication of distress and the loading was apparently well below the failure capacity of the member.

Preliminary calculations indicated a failure capacity of 135 kips, controlled by shear. However, the calculations did not take into account the position of the applied load with respect to the bearing shoe. The load point is $1^{8}-6^{\prime \prime}$ from the bearing point, with a member depth of $1^{8}-9^{\prime \prime}$ at the shallow end. Much of the applied load probably travelled to the bearing in axial compression, with the member acting as a short column. Positioning of the applied load further from the bearing point would have resulted in a more realistic combination of shear with the bearing stresses.

At any rate, the joirt functioned satisfactorily and the reinforcing pattern appeared adequate. 

